\title{
TAPHONOMY OF RECENT FRESHWATER MOLLUSCAN DEATH ASSEMBLAGES, TOURO PASSO STREAM, SOUTHERN BRAZIL
}

\author{
CARLA BENDER KOTZIAN \\ Departamento de Biologia, UFSM, 97105-900, Santa Maria, RS, Brazil.modrizralok@hotmail.com \\ MARCELLO GUIMARÃES SIMÕES \\ Instituto de Biociências, UNESP, Campus de Botucatu, Rubião Júnior, Cx.P. 510, 18618-000, Botucatu, SP, Brazil. \\ btsimoes@ibb.unesp.br
}

\begin{abstract}
Qualitative and quantitative taphonomic data for the freshwater mollusk shells from death assemblages found in straight and meandering fluvial channels of the Touro Passo Stream, southern Brazil, are here presented. A total of 245 gastropod and 485 bivalve shells were collected and analyzed. Complete valves, showing small chipped margins, dominated the studied shell material. The periostracum was present in the great majority of the mollusk shells, and the ligament was preserved in more than $50 \%$ of the studied bivalves. Gastropod shells were intensively (50\% to $80 \%$ ) encrusted by periphyton and Potamolithus egg capsules. Corrasion is one of the main taphonomic signatures exhibited by the mollusk shells, and are represented by small to large pits and holes found in the internal and external shell surfaces. Some evidences indicate that these were acquired soon after death or even during life. Clearly, the presence/absence and the degree of taphonomic alteration of the shells were mediated by intrinsic factors. Some life habits make difficult the determination of post-mortem nature of some taphonomic signatures. In addition, taphonomic signatures do not vary predictably in shells from thanatocoenoses found in the straight or meandering channels. In part, this is due to the reworking of the Pleistocene mollusk shells from fossil-rich layers found in the sandstones of point bar deposits of the meandering channel. Some qualitative and quantitative data are very similar to those found in shells from muddy, organic rich marine bottoms, where acid conditions prevail. In fact, dissolution seems to be the main taphonomic process affecting the shells from the Touro Passo Stream assemblages. However, abrasion is also important in shell damage and roundness, especially in the shells found in assemblages of the straight channel. The spatial mixing and reworking of shells from the studied fluvial subenvironments, the mixture of recently dead shell with fossil remains, and the complex origin of some taphonomic signatures indicate that paleoenvironmental reconstructions, based on freshwater mollusks shells, must be carefully achieved and complemented by sedimentologic and stratigraphic data, even when conducted in typical potamic areas.
\end{abstract}

Key words: Taphonomy, Bivalvia, Gastropoda, fluvial environment, Cenozoic, thanatocoenoses.

RESUMO - Dados tafonômicos qualitativos e quantitativos para conchas de moluscos de águas doces, encontrados em canais fluviais retilíneos e meandrantes, do riacho Touro Passo, sul do Brasil, são aqui apresentados. No total, 245 conchas de gastrópodes e 485 conchas de bivalves foram coletadas e analisadas. Conchas completas, com margens lascadas dominam as assembléias estudadas. Periostraco está presente na grande maioria das conchas examinadas e o ligamento está preservado em cerca de $50 \%$ das conchas de bivalves estudados. Conchas de gastrópodes estão intensamente ( $50 \%$ a 80\%) cobertas por perifíton e cápsulas de ovos de Potamolithus. Corrosão é a principal assinatura tafonômica exibida pelas conchas de moluscos, sendo representada por perfurações de pequeno a grande porte, encontradas tanto na superfície externa, como interna das conchas. Algumas evidências indicam que estas feições foram adquiridas rapidamente após a morte ou mesmo em vida. Claramente, a presença/ausência e o grau de alteração tafonômica de muitas conchas foram influenciados por fatores intrínsecos. Alguns modos de vida, como o de epifauna, tornam difícil a determinação do caráter post-mortem de algumas assinaturas tafonômicas (e.g., incrustação, abrasão). Ainda, as assinaturas tafonômicas não variam previsivelmente segundo os subambientes estudados (lótico e lêntico). Em parte, tal fato decorre do retrabalhamento e mistura de conchas de moluscos pleistocênicos, dada a erosão de arenitos fossiliferous, em depósitos de barras de pontal, junto ao canal meandrante. Alguns dados qualitativos e quantitativos (e.g., alta proporção de conchas com dissolução) são similares aos verificados em ambientes marinhos, com substratos argilosos, ricos em material orgânica e água intersticial ácida. De fato, dissolução/corrosão são os principais agentes tafonômicos de alteração das conchas das assembléias do rio Touro Passo. A abrasão é também um agente tafonômico importante, especialmente no canal retilíneo. A mistura espacial e o retrabalhamento de conchas entre os subambientes amostrados, a mistura de conchas recentemente mortas, com restos esqueletais pleistocênicos e subfósseis, e a complexa origem de algumas assinaturas tafonômicas indicam que as reconstruções paleoambientais fundamentadas em assembléias de moluscos de águas doces deve ser feita com cautela e complementadas por dados sedimentológicos e estratigráficos, mesmo quando em ambientes potâmicos.

Palavras-chave: Tafonomia, Bivalvia, Gastropoda, ambiente fluvial, Cenozóico, tanatocenose. 


\section{INTRODUCTION}

In the last three decades, our taphonomic knowledge on the processes and agents involved in the genesis of the Phanerozoic, marine molluscan shelly concentrations was improved considerably (see a revision in Best \& Kidwell, 2000). Consequently, our understandings on the temporal resolution and paleoecological limitations offered by the data entombed in those shell-rich, marine assemblages are now more accurate than ever, favoring the more precise and faithful paleoenvironmental interpretations. Comparatively to the taphonomic studies of marine assemblages, the freshwater mollusk-dominated accumulations have received limited attention. Hence, data available is scarce and restricted to certain regions of the globe (Northern Hemisphere). In general, such studies focused on the compositional fidelity, taphonomy, and time-averaging of the assemblages found in lacustrine and fluvial environments (Pip, 1988; Cohen, 1989; Briggs et al., 1990; Cummins, 1994; Brown et al., 2005). However, studies on the origin of the taphonomic signatures and their distribution, according to the different freshwater environments, are still missing. In part, this is because the richness (S) of the freshwater mollusk assemblages is lower than that of the marine counterparties. In addition, some freshwater species of mollusk bivalves seem comparatively less specialized in relation to environmental attributes, such as the substrate type (grain size) (Tevesz \& McCall, 1979). Consequently, it is difficult to reconstruct the hydrodynamic and sedimentologic conditions of ancient fluvial systems, on the bases of the functional anatomy of the freshwater shells. The same is not true for the marine bivalves, as the classical study of Stanley (1970) demonstrated. On the other hand, the acid conditions and low calcium carbonate content of fluvial water favor intense dissolution of the mollusk shells (Alexandersson, 1972; Pip, 1988; Kidwell \& Bosence, 1991). These conditions low the preservational potential of these skeletal remains, avoiding the genesis of densely packed shell concentrations (coquina-like, see Gray, 1988). In other words, in comparison with the marine settings the availability of mollusk shells in fluvial environments tends to be smaller.

Despite of the limitations above, the geological record of the freshwater shelly assemblages are very important to paleoecological and paleoenvironamental reconstructions (Gray, 1988). Such concentrations are also fundamental to the stratigraphy of Cenozoic deposits (Guerra \& Cunha, 1998; see Holz \& Simões, 2004). Thus, despite of the inherent difficulties of the study of freshwater molluscan assemblages, some questions must be addressed, including: (i) how do the taphonomic signatures behave (e.g., disarticulation, fragmentation, encrustation, dissolution) in qualitative and quantitative ways, in different freshwater subenvironments and/or facies? (ii) are the taphonomic signatures of shells deposited under fluvial and lacustrine conditions remarkably different from those of marine environments? (iii) are the taphonomic signatures of the gastropod species (essentially "epifaunal") distinct of the co-occurring bivalve shells? (iv) are the compositional and spatial fidelity and time-averaging of freshwater molluscan assemblages comparable to those of lacustrine and plataformal environments?

Shelly assemblages of the Touro Passo Stream offer us a unique opportunity to address some of the issues above. This is because the common occurrence of bivalve shells in thanatocoenoses of this stream (Oliveira, 1989, pers. comm.). Touro Passo Stream periodically experiences dryness events, sometimes with the exposure of the riverbed, making samplings easier. The course of the Touro Passo Stream shows distinct sectors, including channels of different types, such as straight and meandering to braided. The latter one have lentic habitats and facies (Bombin, 1976), including secondary and intermittent channels, allowing the analyses of the influence of extrinsic factors (water energy) on the taphonomy of shells. Besides, in some sites, river terraces made by Pleistocene-Holocene sediments enclose mollusk shells (Bombin, 1976; Oliveira \& Milder, 1990; Oliveira, 1996). This allows the study of time-averaging and preservational potential of the freshwater shells found in the thanatocoenoses. Thanks to studies focusing the freshwater molluscan fauna of the state of Rio Grande do Sul (see Veitenheimer-Mendes et al., 1986, 1992; Mansur \& Garces, 1988; Mansur et al., 1991, 1994, 2001; Lanzer, 1996, 1997; Pereira et al., 2000a,b, 2001; Paraense, 2001; Simões, 2002; Silva, 2003) and adjacent areas (Uruguay, Argentina, and Rio da Prata Basin, see Di Persia \& Olazarri, 1986; López-Armengol \& Darrigran, 1998; Martínez \& Rojas, 2004), the taxonomy, geographic distribution and life habits of gastropods and bivalves are relatively well known, favoring taphonomic studies addressing the compositional and spatial fidelity of Touro Passo Stream shells.

In the context above, this paper aims to contribute to our understandings of the taphonomy of the molluscan shells in a subtropical fluvial environment. In this way, some poorly explored issues are tentatively addressed, such as the origin of some taphonomic signatures (e.g., disarticulation, fragmentation, encrustation and corrosion, sense Brett \& Baird, 1986; Kidwell \& Bosence, 1991), and the spatial fidelity of freshwater molluscan species. In particular, the differences in the taphonomy of molluscan shells from two fluvial subenvironments, straight (typically lotic), and meandering (partially lentic) were evaluated.

\section{MATERIAL AND METHODS}

\section{Study area}

The Touro Passo Stream is a tributary of the Uruguay River and is located between Ibicuí and Quaraí rivers $\left(29^{\circ} 45^{\prime} \mathrm{S} /\right.$ $57^{\circ} 05^{\prime} \mathrm{W}$ Gr.), in Uruguaiana County, western of the state of Rio Grande do Sul (Figure 1). The river flows for about $55 \mathrm{~km}$, draining a basin of $800 \mathrm{~km}^{2}$. The morphology of the channel is straight, intercalated by sectors showing meandering to braided channels (Bombin, 1976). The altitude in the headwaters is $140 \mathrm{~m}$ (a.s.1.), decreasing to $40 \mathrm{~m}(\sim 0.35 \mathrm{~m} / \mathrm{km})$ near the stream mouth at the Uruguay River. Hence, the base level of the Uruguay River controls the discharge and the stream flow, which during flooding events can be enclosed 


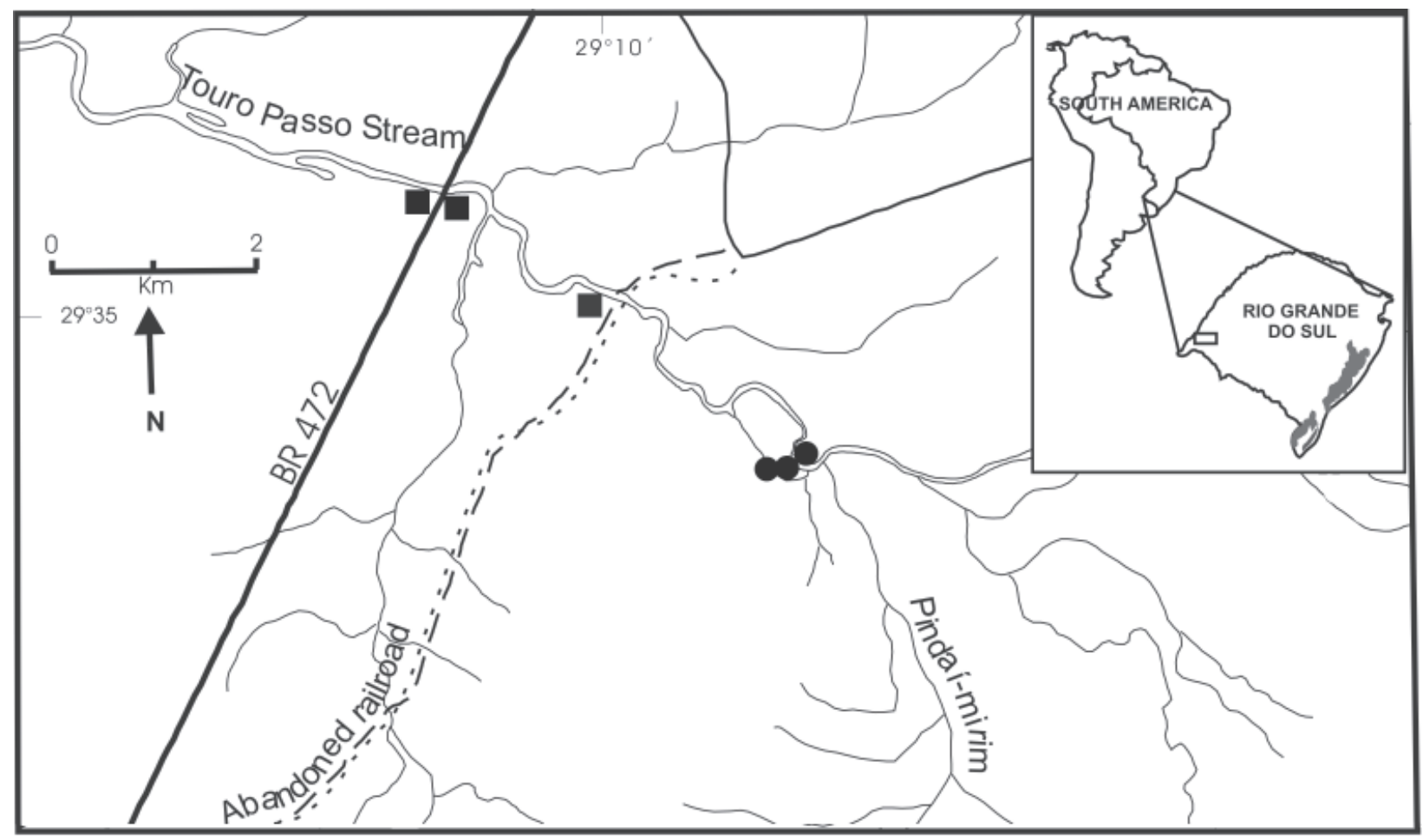

Figure 1. Schematic map showing the location of the sampling areas in the middle course of the Touro Passo Stream: substations of the straight (square) and meandering (circle) sections.

up to $15 \mathrm{~km}$ from its mouth (Bombin, 1976). Exposures of rocks of the Touro Passo Formation are observed at $35 \mathrm{~km}$ from the stream mouth. This unit is Late Pleistocene-Holocene in age, correlating with the Sopas Formation, in Uruguay, and Luján Formation, in Argentina (Bombin, 1976). According to the formal lithostratigraphy, the Touro Passo Formation encompasses two members. The lower member is rudaceous, including reworked Pleistocene mammal fossils. The upper member is muddy, and essentially made-up of siltstones or siltic to siltic-clayed sandstones, locally containing a volcanic ash layer. This member also bears invertebrate and vertebrate skeletal remains, as well as archaeological materials. According to Bombin (1976), molluscan subfossil shells and archaeological material of "younger traditions" from this member are 3.500 years old in age (Bombin, 1976).

The climate of the region can be classified as type $\mathrm{Cfa} 2$ (Köppen's system, Moreno, 1961). The mean annual temperature is $16^{\circ} \mathrm{C}$, with maximum averages of $25^{\circ} \mathrm{C}$ and minimum averages of $14^{\circ} \mathrm{C}$. However, the absolute maximum temperature can reach up to $40^{\circ} \mathrm{C}$ and the minimum, about $4^{\circ} \mathrm{C}$ (Machado, 1950; Moreno, 1961). The mean annual precipitation is $1356 \mathrm{~mm}$, with the pluviometric regime controlled by Pacific and Atlantic anticyclones. According to the predominance of these anticyclones, dry, wet or warm conditions with high humidity, but no rain can occur. These conditions characterize a subtropical climate, without a well definite dry season, and with a few precipitations during the winter (Bombin, 1976).

Finally, the vegetation of the studied region is classified as estepe (locally named Campanha Gaúcha) (Leite \& Klein, 1990), and is characterized by grasslands.

\section{Mollusks from the Touro Passo Formation}

Currently, about 13 species of mollusks are assigned for the Touro Passo Formation, including: a- bivalves, Anodontites trapesialis (Lamarck), Leila blainvilliana (Lea), Diplodon delodontus wymani (Lea), Diplodon sp., Neocorbicula limosa (Maton), and Neocorbicula sp., and b- gastropods, Heleobia piscium (Orbigny); H. parchapii (Orbigny), H. australis (Orbigny), Heleobia sp., Potamolithus lapidum (Orbigny), P. petitianus (Orbigny) and Gundlachia sp. (Bombin, 1976; Oliveira \& Milder, 1990; Oliveira, 1996).

\section{Mollusks from the Touro Passo Stream}

Oliveira (1989) recorded 15 species of native bivalves, including: A. trapesialis forbesianus (Lea), A. tenebricosus (Lea), A. ferrarisi (Orbigny), A. patagonicus (Lamarck), $A$. trapezeus (Spix), Anodontites sp., Mycetopoda legumen (Martens), M. siliquosa (Spix), Monocondylaea minuana (Orbigny), M. corrientensis (Orbigny), D. delodontus wymani, D. parallelopipedon (Lea), D. rhuacoicus (Orbigny), Castalia ambigua inflata (Orbigny), N. limosa. In addition, an exotic species [Corbicula fluminea (Müller)] was also recorded by Oliveira (1989).

\section{Collecting stations and sampling methodology}

The study area was restricted to the mid course of the Touro Passo Stream (Figure 1), a non-regulated sector (without dams). According to Strahler's classification (Strahler, 2004), the mid course of the Touro Passo Stream can be classified as $4^{\text {th }}$ order stream.

Two sampling stations were established in two distinct sectors of the river (straight, and meandering to braided) 
(Figure 1), according to the accessibility to the channels. In the meandering to braided sector, which shows high and steep terraces in both margins, the mollusks were only collected during the dry seasons. In the straight sector, due to the gentle slopes of the left margin, mollusk shells were collected during dry and wet seasons, including the flooding periods. It is important to emphasize here that during the dry seasons, mollusk shells are always trapped in small shoals of the straight channel. During the wet season, the shoals (including the trapped shells) are covered by water and will be reexposed during the next dry season.

The stations are characterized as follow: Station 1 straight sector, situated between the highway BR 472 and an old railroad (56 $52^{\prime} 20^{\prime \prime} \mathrm{W}, 29^{\circ} 39^{\prime} 47^{\prime}$ 'S). During the dry periods, channel width and depth ranged from 10 to $20 \mathrm{~m}$, and from 1.50 to $1.60 \mathrm{~m}$, respectively (Oliveira, 1989). Water $\mathrm{pH}$ measured during the field trips ranged from 6.4 to 6.5 . The bottom includes silts and coarse sands, and fine sands and clay, subordinately (Oliveira, 1989). The mollusks were collected only in the left margin, with grades ranging from $0^{\circ}$ to $45^{\circ}$. This area represents a slightly shaded flood plain. Small marshes are also very common in this sector. However, connections between them and the main river channel only occur during the periods of overflow. Station 2 - meandering sector: located immediately downstream of the confluence with the Pindaí Stream (56 $51^{\prime} 39^{\prime \prime} \mathrm{W} / 29^{\circ} 41^{\prime} 8.3^{\prime \prime}$ 'S). In the main channel, the width and the depth have about $6 \mathrm{~m}$ and $1 \mathrm{~m}$, respectively (Oliveira, 1989). The margins are delimitated, in the right side, by a $3 \mathrm{~m}$ high, steep terrace. In the left side, the margin is delineated by a point bar, which encloses 18.570 to 20.690 years old mollusk fossils. The riverbed is made-up by basaltic rocks, whereas coarse sands and silts, fine sands and clay are the main sediments found in the margins (Oliveira, 1989). Locally, granules, pebbles and cobbles are also found in the margins (Oliveira, 1989). The secondary channel, with nearly $6 \mathrm{~m}$ of width has, in the left margin, a $3 \mathrm{~m}$ high, sandy terrace. In this terrace, shells of fossil mollusks are also found. A sandy point bar, and the basaltic riverbed delimit the right margin. Mollusk specimens were also collected in small and narrow channels $(1 \mathrm{~m}$ of depth) in the point bar. This constitutes a vegetated island. Channels have steep margins, muddy to sandy bottoms, with few aquatic plants. During flooding, the primary and secondary channels may reach $3 \mathrm{~m}$ of depth. Obtained $\mathrm{pH}$ values for the water in the primary and secondary channels varies from 6.4 to 6.3 , respectively. In the narrow channel of the point bar the recorded $\mathrm{pH}$ values are 6.0 to 5.5 .

Additionally, mollusk shells were also sampled in a small, 1 meter depth, $1^{\text {st }}$ order (sensu Strahler, 2004) tributary of the Touro Passo Stream. This tributary is in the straight sector (Station 1) and is partially dammed. As a consequence, its hydrodynamic is similar to an abandoned meander with aquatic plants [Nymphoides indica (L.) Ktze].

\section{Sampling of the thanatocoenoses}

In the study area, shell accumulations are thin and sparse and were sampled in February (dry period) and May (flood period) of 2003. Following Cummins (1994), mollusks were collected by means of quadrats, with sampling area of $5 \mathrm{~m}^{2}$. For each stream sector (stations 1 and 2), samplings were done in three substations. For each substation, three quadrats were done, as follow: two submersed quadrats, and one subaerial (exposed area) quadrat. In summary, nine quadrats were done per stream sector (stations 1and 2), encompassing a total area of $45 \mathrm{~m}^{2}$. Sediments in the interior of the quadrats were sampled via $1 \mathrm{~mm}$ mesh sieves. Shells and shell fragments found in the sediments were carefully picked apart and stored in plastic bags. However, shells in the sediments of the subaerial quatrats were manually collected. In the sector represented by an "abandoned-like meander", where macrophytes are present inside the sampling area, shells were directly picked from the vegetation. To do this, macrophytes were removed from the water and individually examined for the presence of mollusks.

In the laboratory, when necessary, the dead shells were carefully washed and brushed to remove the sediments of the interior of the valves.

Whenever possible, the methodology used followed the procedures currently adopted in quantitative taphonomic studies on marine molluscan thanatocoenoses (see reviews in Kidwell et al., 2001; Kowalewski \& Hoffmeister, 2003; Hannisdal, 2004). However, due to the small number of specimens obtained in some substations, it was not possible to separately analyze the taphonomy of shells according to the size-classes.

All mollusk shells in this study are deposited in the scientific collection of the Setor de Zoologia, Departamento de Biologia, of the Universidade Federal de Santa Maria (UFSM), Brazil.

\section{Taphonomic Signatures}

The description, terminology, and the type of taphonomic signatures (Figure 2; Table 1) here analyzed were adapted from Parsons \& Brett (1991), Kowalewski et al. (1994), Anderson et al. (1998), and Henderson et al. (2002). However, unique taphonomic signatures were also recognized, such as the presence of "proteinaceous parts". This signature records not only the presence of periostracum, but also the ligament and operculum (Table 1). Taphonomic signatures were examined using $10 \mathrm{x}$ of magnification under the stereomicroscope. However, the shells of young specimens or very small species (approximately $1 \mathrm{~cm}$ ) were studied at higher magnification.

As discussed below, abrasion and dissolution may act together in shell destruction. For this reason, dissolution and abrasion were grouped in one category, namely "corrasion" (see Brett \& Baird, 1986; Parsons \& Brett, 1991). In order to facilitate the discussion, levels of corrasion were determined informally, according to the Table 1.

\section{Ecological characterization of the thanatocoenoses}

Analyzes of the taxonomic and ecologic composition of members of the studied thanatocoenoses were carried out in order to identify the degree (allochthonous/autochthonous) 

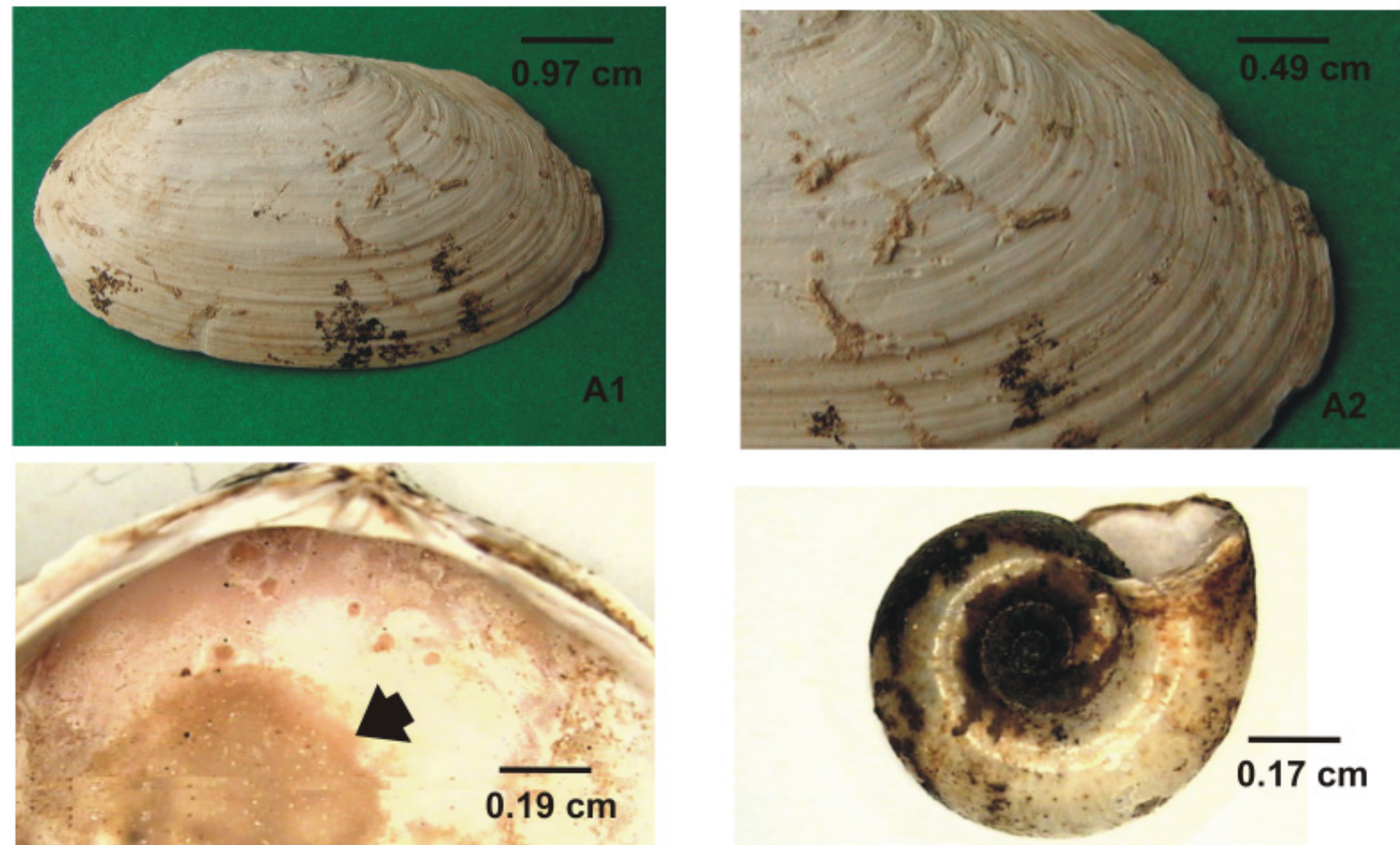

B

C
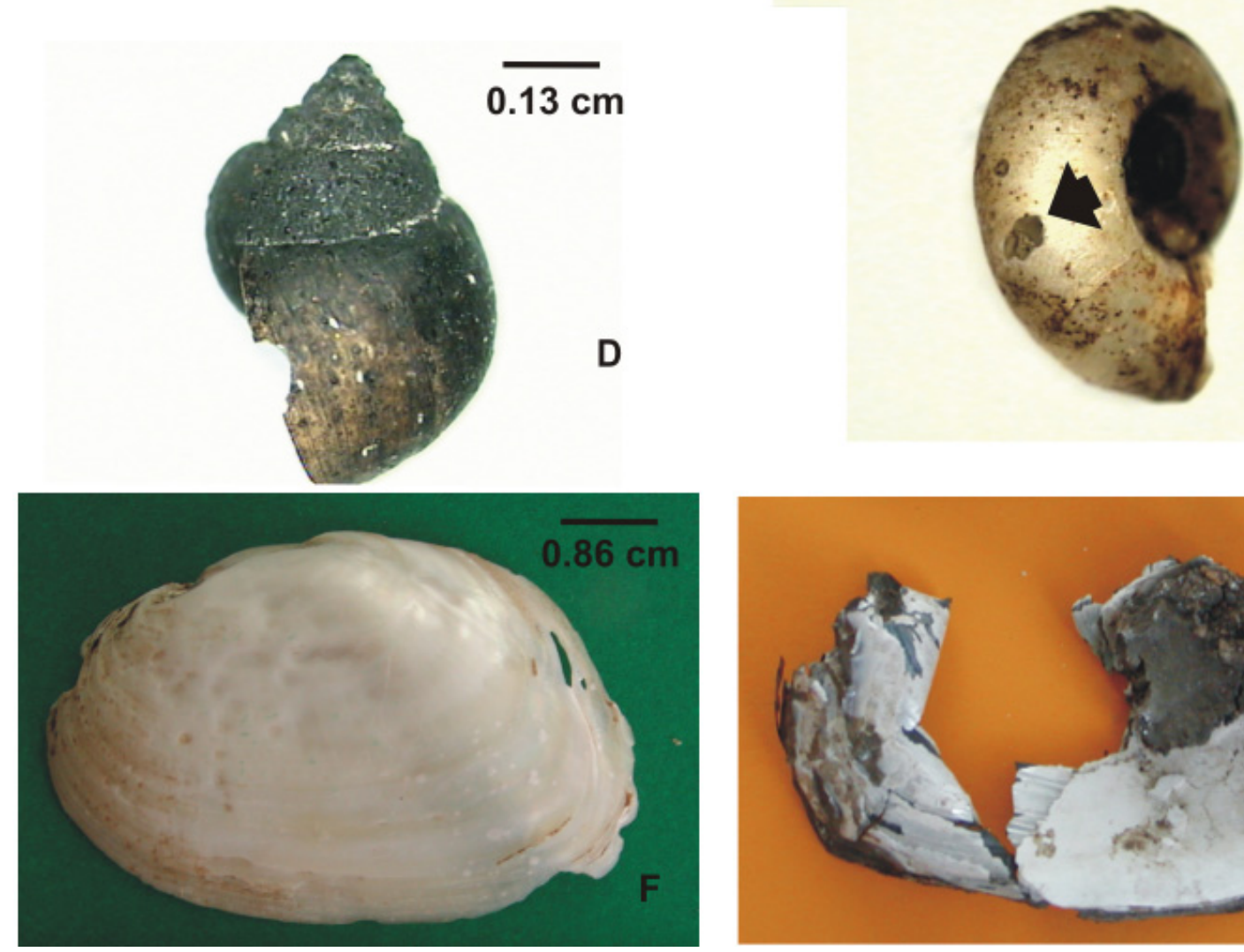

$0.14 \mathrm{~cm}$

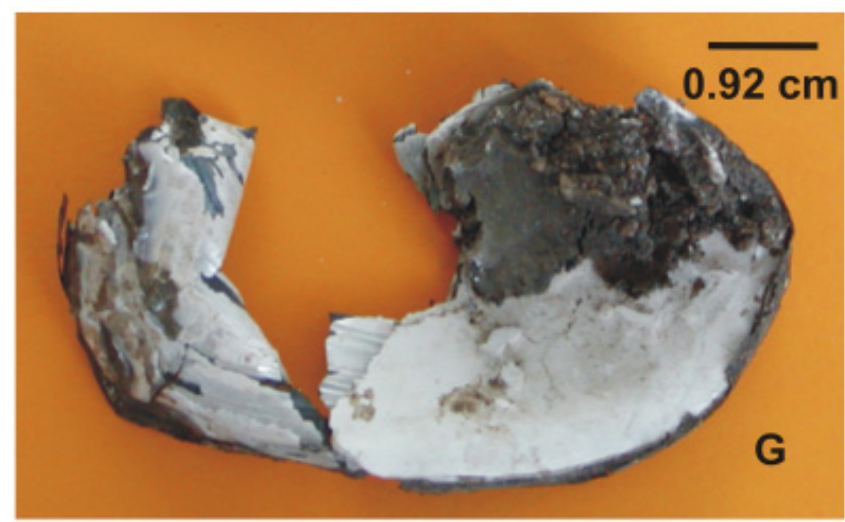

Figure 2. Taphonomic signatures. A1, CaCO3 tubes on valve of $D$. rhuacoicus; $\mathbf{A} 2$, detail of figure $\mathrm{A} 1$; $\mathbf{B}$, calcite crystals on the internal surface of the valve of $\mathrm{N}$. limosa; $\mathbf{C}$, deposit of ferruginous material on shell of Biomphalaria sp.; $\mathbf{D}$, deposit of ferruginous material on shell of $P$. aff. orbigny; $\mathbf{E}$, periostracum recovering hole (arrow) on shell of Biomphalaria sp.; $\mathbf{F}$, probable abrasion (facet) on the posterodorsal region of shell of $D$. delodontus wymani; $\mathbf{G}$, internal view of a heavily dissolved valve of $D$. delodontus wymani, supported by periostracum. 
Table 1. List of the taphonomic attributes analyzed in this paper with referring remarks and processes.

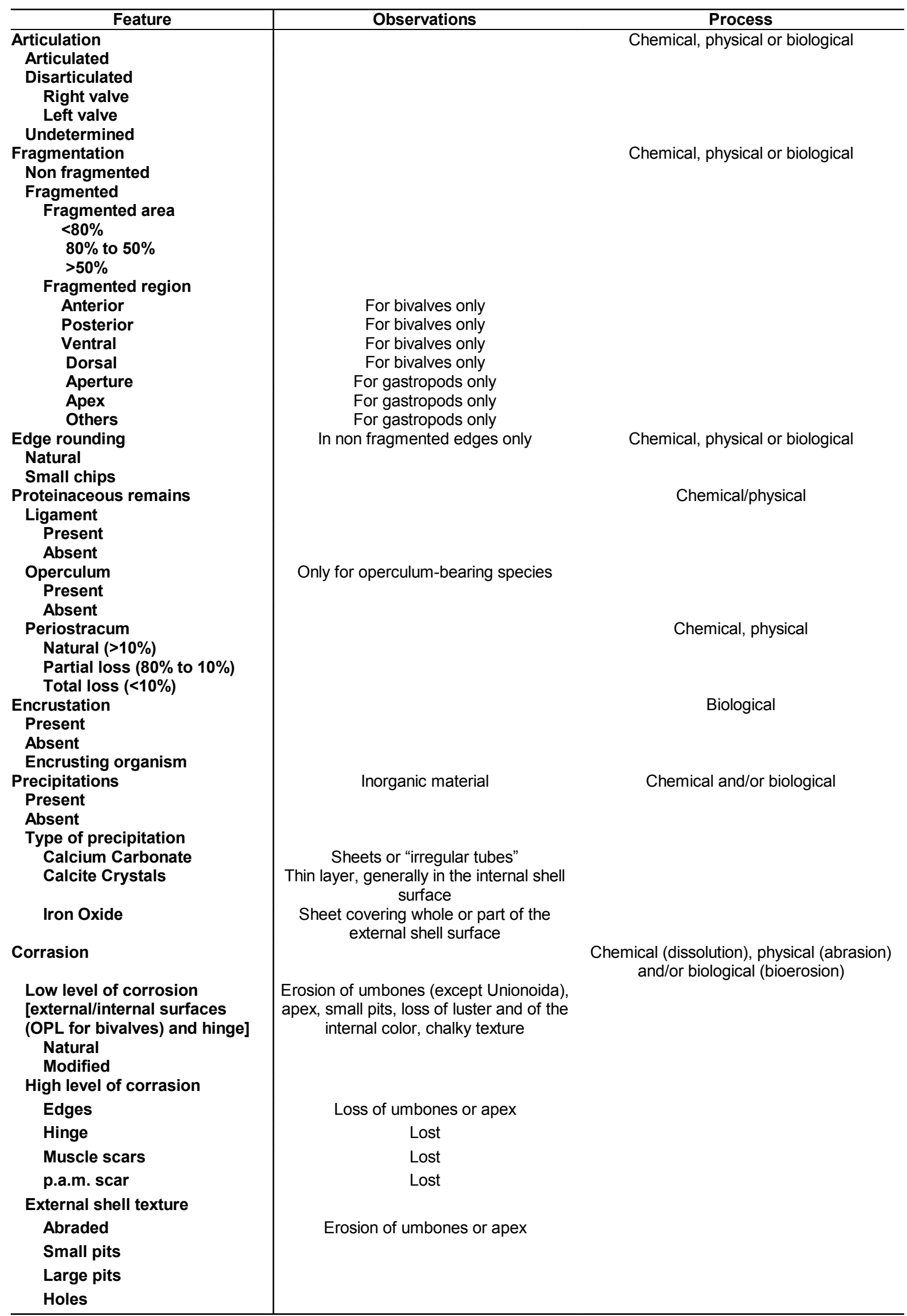


of post-mortem spatial mixing. Among the studied mollusks only a few species have narrow range of ecological requirements. In addition, there are only a few ecological studies (e.g., Henry \& Simão, 1985; Duarte \& Diefenbach, 1994; Duarte et al., 1996; Lanzer \& Shäefer, 1985, 1987, 1988) on the Modern freshwater molluscan fauna of the rivers in the state of Rio Grande do Sul and neighboring regions (Uruguay and Argentina). Hence, the ecological analysis presented here is only tentative.

The following ecological parameters and categories were included in this study: (i) Bottom type (grain size): muddy, sandy/pebbly, and stony (cobble/boulder); (ii) Hydrodynamic regime: lentic (swamps, lakes and dams); and lotic (streams and rivers); (iii) Mode of life: epifaunal and infaunal; (iv) Feeding behavior: filter-feeding, herbivorous, detritivorous, carnivorous (predator); and (v) Ecological interactions: mollusk-aquatic plants interaction, species that can be considered as pleuston/bafon, at least, in part of the life cycle.

Two different approaches were used in the ecological analysis. In the exhaustive approach, all the recorded molluscan habits were considered. In this case, the abundance of the species included in more than one category was repeated in all of them. In the restrictive approach, only the preferential habit/habitat was included in each category.

\section{Quantitative analyses}

During the taxonomic and ecologic analyzes (richness and/or abundance), the number of disarticulated valves of the bivalve shells was corrected by a factor of 0.5. This procedure is needed when bivalved and univalved invertebrates (e.g., gastropods) are analyzed all together (see Kowalewski et al., 2003).

In many cases, the number of obtained valves per species was low, allowing us to identify the originally matching valves (belonging to the same individual). In only one case, including 93 disarticulated valves of $C$. largillierti (sub-aerial quadrat, $1^{\text {st }}$ substation, straight sector), this procedure was not employed. Hence, based on Gilinski \& Bennington (1994), two distinct analytical approaches were adopted, including the XNI (maximum number of individuals), and the MNI (minimum number of individuals) (see Results).

Gastropod and bivalve shells were considered separately in the taphonomic analysis. The frequencies of the taphonomic signatures were analyzed using non-binomial $95 \%$ confidence intervals. In the analysis of the frequencies of taphonomic signatures between stations a $5 \%(\mathrm{p}<0.05)$ level of significance was used.

\section{RESULTS}

\section{Taxonomic composition, abundance and richness of the thanatocoenoses}

In both stream sectors (straight, meandering to braided), a total of 730 specimens ( 245 gastropods, 485 bivalves) were collected. Bivalve shells were assigned to 14 species, whereas the gastropods were attributed, at least, to five species, only. The gastropods are represented by Pomacea canaliculata,
P. aff. orbigny, Heleobia spp., Gundlachia moricandi and Biomphalaria spp., and the bivalves, by Anodontites trapesialis forbesianus, A. patagonicus, A. ferrarrisi, Anodontites sp., Diplodon delodontus wymani, D. rhuacoicus, D. parallelopipedon, Diplodon sp., Monocondylaea minuana, M. legumen, C. largillierti, $N$. limosa, E. klappenbachi and P. punctiferum.

Richness is higher in assemblages of the meandering sector (17 genera and/or species) than in those from the straight sector (10 genera and/or species), even when gastropods and bivalves are analyzed separately. However, the abundance was higher in the latter. In all sectors, the abundance and the richness were always higher for bivalve shells than for gastropod shells (Table 2).

In the straight sector, the dominant species was the exotic, invasive bivalve $C$. largillierti, followed by the gastropods $P$. aff. orbigny and $P$. canaliculata. In the meandering sector, the dominant species was $D$. delodontus wymani, followed by $P$. aff. orbigny and $P$. canaliculata (Table 2).

Taking into account the gastropods, the following species are dominant: $P$. aff. orbigny, $P$. canaliculata and Biomphalaria spp. In the straight sector, $C$. largillierti was the dominant bivalve species, comprising $87 \%$ of the specimens (XNI approach), followed by $D$. delodontus wymani $(17 \%)$. The former species is still dominant $(82 \%)$ when the MNI approach is used. In the meandering sector, D. delodontus wymani is the dominant bivalve species (51\%), followed by N. limosa and C. largillierti (Table 2).

All the gastropod shells recorded in the straight sector were also found in the meandering sector. However, the opposite is not necessarily true. Out of the 19 gastropod species recorded, eight are common in both sectors, including the dominant species.

In the abandoned meander, the following species were assigned: $P$. aff. orbigny, P. canaliculata, Biomphalaria spp., G. moricandi, Gundlachia obliqua, A. trapesialis, and $P$. punctiferum.

\section{Ecological composition}

Filter-feeding bivalves predominate in the meandering sector, where lentic conditions prevail (Figure 3). In the exhaustive analysis, the data suggest high frequencies of muddy and lentic dweller mollusks (Figure 3). In any analysis, high frequencies of epifaunal mollusks and/or species that are associated with aquatic plants occurred (Table 2; Figure $3)$. As previously commented, aquatic plants are rare in the stream, only occurring in the secondary and small channels of the meandering sector and in tributaries of the straight sector. Notably, shells of those mollusks were more numerous in the straight, than in the meandering sector (Figure 3).

\section{Taphonomic signatures}

Disarticulation. The frequency of disarticulated shells is significantly higher (about 80\%) in the straight sector (Figure 4) than in the meandering sector, even when the data from the sub-aerial quadrat ( $1^{\text {st }}$ substation) is analyzed using the restrictive approach (77\%). Yet, the left-right phenomenon 
(term used by Lever, 1958 to the excess of left or right valves in accumulations of clam shells) was not observed in the studied thanatocoenoses from accumulations of both sectors (Figure 4).

Fragmentation. Low fragmentation frequencies $(<35 \%)$ were observed for both groups (gastropod and bivalve shells) (Figure 5). However, fragmentation was more frequent in gastropod shells of the straight sector, whereas bivalve shells from the meandering sector are more fragmented. In both cases, the results are significantly different $(\mathrm{p}<0.05)$.

Less than $25 \%$ of the studied bioclasts can be interpreted as fragments (i.e., particles representing less than $50 \%$ of the original shell). In fact, the great majority of bivalve shells from both sectors are well preserved (i.e., with $50 \%$ to $80 \%$ of total shell area unfragmented) (Figure 6A). In the same way, most of gastropod shells showed less than $80 \%$ of the shell area broken (Figure 6B).

In spite of the observed low fragmentation frequencies, the posterior region of bivalve shells, and the apertural area of gastropod shells are the areas that are more prone to fragmentation (Figure 7). However, these results are not significant. In fact, significant differences $(p<0.05)$ were only observed for the fragmentation in the ventral margin of the bivalve shells from straight and meandering sectors. Finally, cracks on gastropod and bivalve shells were also infrequent in the studied assemblages of both sectors.
Margin roundness. Shells showing chipped margins are common in accumulations from the straight and meandering sectors. However, this taphonomic signatures is more significant $(p<0.05)$ in shells found in assemblages of the straight sector (Figure 5).

Presence of proteinaceous remains. In all studied accumulations, bivalve shells yielding preserved ligament were frequent $(>50 \%)$, especially those from samples of the straight sector (Figure 8A). On the other hand, in the gastropod shells the presence of operculum was rare $(<15 \%)$, and only a few isolated opercula were recorded in samples from the straight sector (Figure 8B).

For both groups (gastropods and bivalves), the partial loss of periostracum is infrequent (generally $>50 \%$ ) (Figure 8 ). This is well observed in shells from samples of the straight sector, where shells showing the partial loss of periostracum are more frequent, followed by those smooth shells.

Encrustations and Precipitations. Encrustation occurred in more than $50 \%$ of the gastropod shells, being more significant $(p<0.05)$ in shells of the meandering sector (Figure 9B). Encrustation was rare in bivalve shells (less than 20\%) from both sectors (Figure 9A), but the results are not significantly different $(\mathrm{p}>0.05)$. The external surface of gastropod shells are generally covered by stalked and filamentous periphyton, and egg capsules of Potamolithus. On the other hand, the

Table 2. Taxonomic composition, number of specimens, environmental preferences and life habits of the species registered in the station 1 (straight section) and 2 (meandering section) of the Touro Passo Stream, RS. AP, association with plants; EP, epifaunal; LE, lentic; LO, lotic; MD, muddy; SD, sandy/pebbly; ST, stony; $\mathbf{a}$, adult; $\mathbf{p}$, probable; $\mathbf{x}$, occurrence; $\mathbf{y}$, young. Note: capital letters to preferential life habits/ environments.

\begin{tabular}{|c|c|c|c|c|c|c|c|c|c|c|}
\hline & 1 & 2 & Total & ST & SD & MD & LE & LO & EP & AP \\
\hline A. ferrarisi & $0(0)$ & $2(2)$ & $2(2)$ & & $x$ & $x$ & & & & \\
\hline A. patagonicus & $0(0)$ & $1(1)$ & 1(1) & & $x$ & $x$ & $x$ & & & \\
\hline A. trapesialis forbesianus & $2(2)$ & $5(4,5)$ & $7(6,5)$ & & $x$ & $x$ & $x$ & & & \\
\hline Anodontites sp. & $2(1)$ & $0(0)$ & $2(1)$ & & & & & & & \\
\hline M. minuana & $0(0)$ & $4(3)$ & $4(3)$ & & & & & & & \\
\hline M. legumen & $0(0)$ & $1(1)$ & $1(1)$ & & & & & & & \\
\hline D. delodontus wymani & $21(14)$ & $88(65,5)$ & $109(79,5)$ & & $\mathrm{p}$ & $\mathrm{p}$ & $\mathrm{p}$ & & & Y/a \\
\hline D. parallelopipedon & $2(1)$ & $0(0)$ & 2(1) & & & & & & & Ya \\
\hline D. rhuacoicus & $0(0)$ & $3(1,5)$ & $3(1,5)$ & & $p$ & $\mathrm{p}$ & $x$ & & & $\mathrm{Y} / \mathrm{a}$ \\
\hline Diplodon sp. & $0(0)$ & $1(0,5)$ & $1(0,5)$ & & $\mathrm{p}$ & $\mathrm{p}$ & p & & & \\
\hline Unionacea (indet.) & 1 & 5 & 6 & & & & & & & \\
\hline C. largillierti & $262(193,5)$ & $31(27,5)$ & $293(221)$ & $x$ & $x$ & $x$ & $x$ & $x$ & $x$ & $Y$ \\
\hline N. limosa & $12(9,5)$ & $32(26,5)$ & $44(36)$ & & $x$ & $x$ & $x$ & $x$ & & \\
\hline E. klappenbachi & $1(1)$ & $1(0,5)$ & $2(1,5)$ & & $x$ & & $x$ & $x$ & $x$ & $A$ \\
\hline$P$. punctiferum & $0(0)$ & $3(1,5)$ & $3(1,5)$ & $x$ & $x$ & $x$ & $x$ & $x$ & a & $A$ \\
\hline Gen. et sp. indet. & $3(3)$ & $4(4)$ & $7(7)$ & & & & & & & \\
\hline BIVALVIA & $317(226)$ & $168(144)$ & $485(370)$ & & & & & & & \\
\hline$P$. aff. orbigny & 76 & 38 & 114 & $x$ & $x$ & $x$ & $x$ & $x$ & $x$ & $x$ \\
\hline Heleobia spp. & 0 & 8 & 8 & $x$ & $x$ & $x$ & $X$ & $x$ & $x$ & $x$ \\
\hline P. canaliculata & 61 & 29 & 90 & $x$ & $x$ & $x$ & $x$ & $x$ & $A$ & $Y$ \\
\hline Biomphalaria spp. & 19 & 13 & 32 & $x$ & $x$ & $x$ & $X$ & $x$ & $x$ & $x$ \\
\hline G. moricandi & 0 & 1 & 1 & $x$ & & & $x$ & $x$ & $x$ & $x$ \\
\hline GASTROPODA & 156 & 89 & 245 & & & & & & & \\
\hline MOLLUSCA & $473(382)$ & $257(233)$ & $730(615)$ & & & & & & & \\
\hline
\end{tabular}

Sources: For Rio Grande do Sul see reviews in Mansur \& Veitenheimer (1975), Chieffi \& Moretti (1979), Davis \& Silva (1984), Mansur \& Garces (1988), Mansur \& Olazarri (1995), Mansur et al. (1991, 1994, 2001), Veitenheimer-Mendes et al. (1986; 1992), Morton (1982), Duarte \& Diefenbach (1994), Lanzer (1996, 1997), Carvalho et al. (1998), Pereira et al. (2000a,b; 2001), Paraense (2001), Simões (2002). For adjacent areas in Uruguay and Argentina (Rio da Prata Basin) see reviews in Parodiz \& Hennings (1965), Bonetto et al. (1982), Di Persia \& Olazarri (1986), Ituarte (1994, 1996), Darrigran (1995), López-Armengol \& Darrigran (1998) and Martínez \& Rojas (2004). 


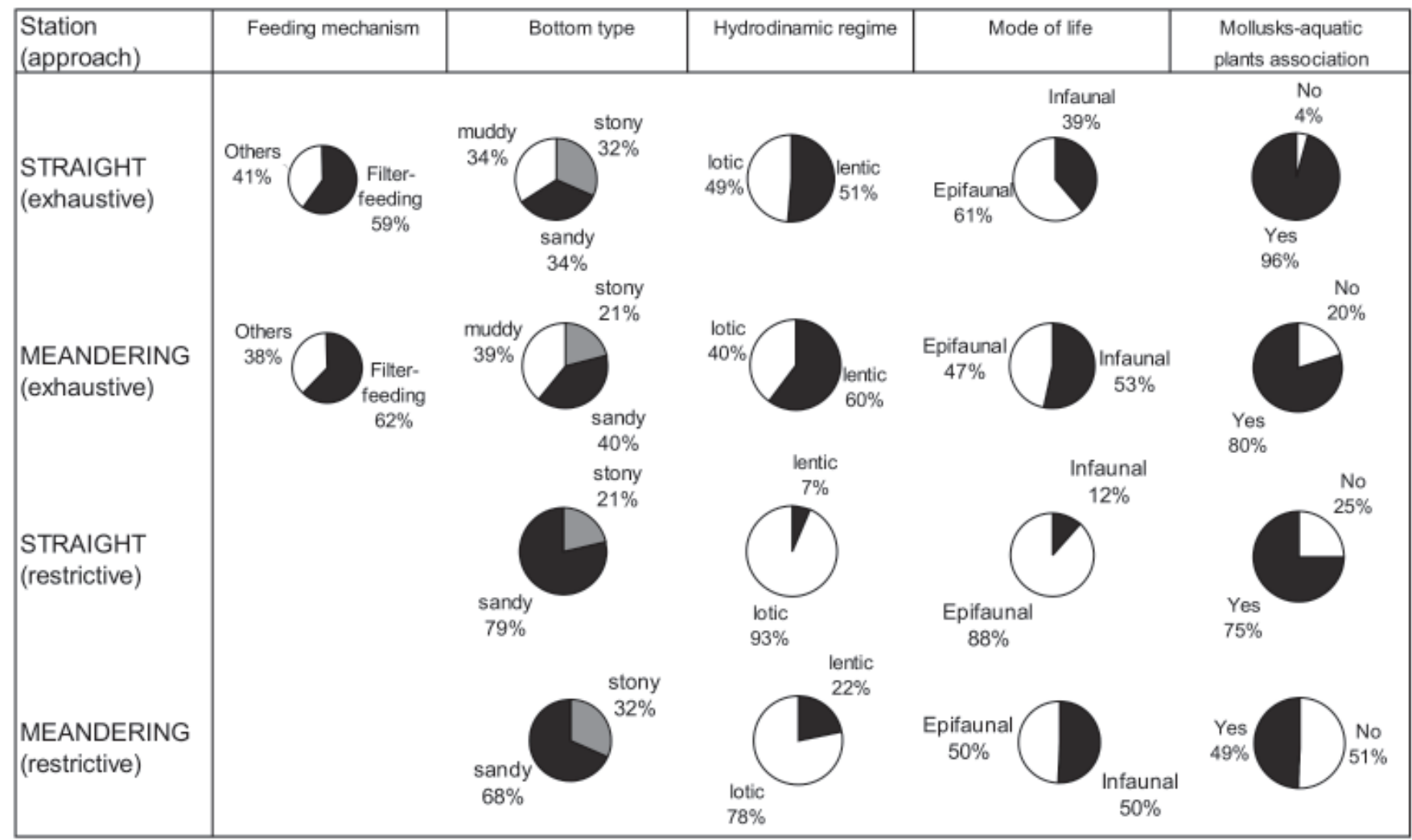

Figure 3. Exhaustive and restrictive analyses of the frequencies of the life habits and habitats of the mollusks collected in the straight and meandering sectors from the Touro Passo Stream.

commonest encrusting organisms on bivalve shells are microscopic algae that are recorded both in the internal and external valve surfaces.

Precipitations are more frequent on gastropods (Figure 9B) than in bivalve shells (Figure 9). However, gastropods from accumulations of both sectors (straight and meandering) show similar proportions of shells yielding carbonatic precipitations. Conversely, for the bivalves precipitations are significantly higher $(\mathrm{p}<0.05)$ in shells from the meandering sector (Figure 9A).

In the bivalve shells, calcite crystals usually cover the external surface of the valves. However, small calcium carbonate tubes may be found in the internal and external surfaces of the shells (Figure 10A). These two types of precipitations are observed in shells from the straight and meandering sectors. In the gastropods, this signature is mainly characterized by the presence of iron oxide deposits that covers the external shell surface. Notably, this deposit can be found in $90 \%$ to $100 \%$ of the gastropod shells from accumulations of the straight and meandering sectors (Figure 10B). Especially in P. aff. orbigny, the iron oxide deposits can be very thick (covering the half of thickness of the external labium of an adult shell). No significant differences $(p<0.05)$ were observed in the frequency of this signature in gastropod shells from the straight and meandering sectors.

Corrasion. Low levels of corrasion (see Table 1) are very frequent in the studied gastropod and bivalve shells. For example, in more than $80 \%$ of the shells from the straight sector, low levels of corrasion are observed in the internal/ external surface of the shells, as well as in the hinge area of bivalve shells (Figure 11). Corrasion is significantly higher ( $p$ $<0.05$ ) in the bivalve shells from the meandering sector. In some cases, at least $35 \%$ of the studied bivalve shells from this sector are severely corroded just in the scar of the posterior adductor muscle (Figure 12A). However, in the bivalve shells

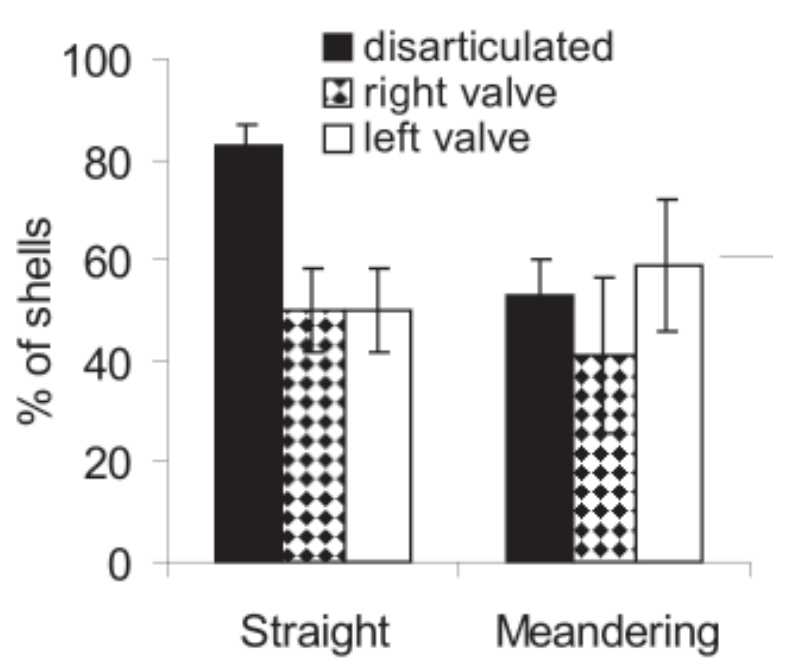

Figure 4. Frequency of disarticulated shells and frequency of right and left valves. Error bars show $95 \%$ confidence intervals. 

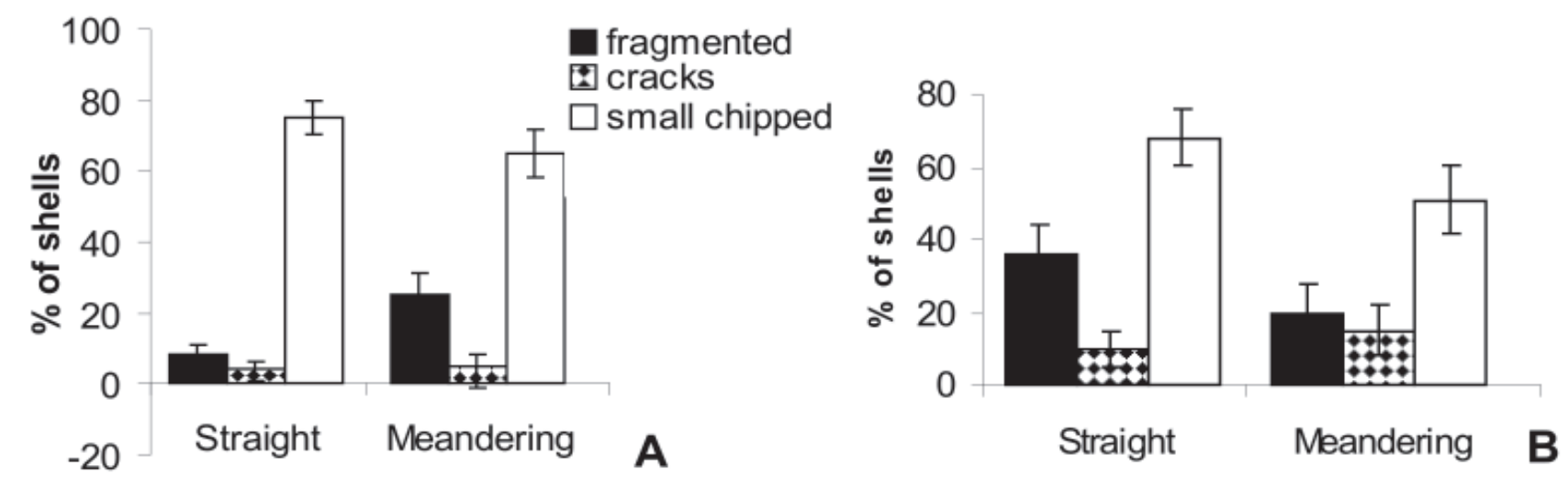

Figure 5. Frequency of fragmentation, cracks and small chipped edges. A, bivalves; B, gastropods. Error bars show $95 \%$ confidence intervals.
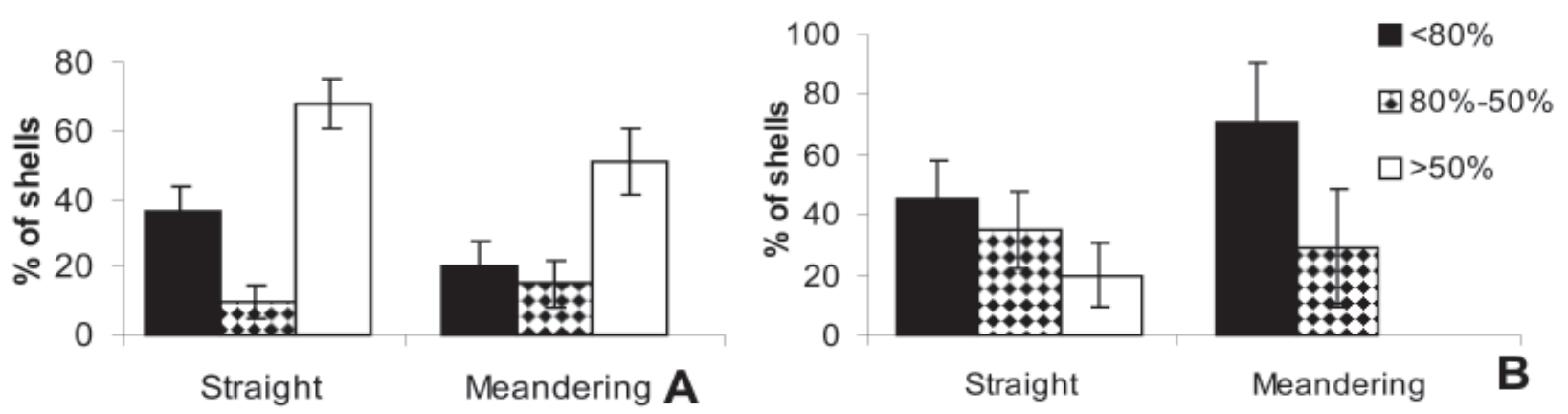

Figure 6. Frequency of the size (percentage) of the fragmented surface areas of the shells. A, bivalves; B, gastropods. Error bars show $95 \%$ confidence intervals.
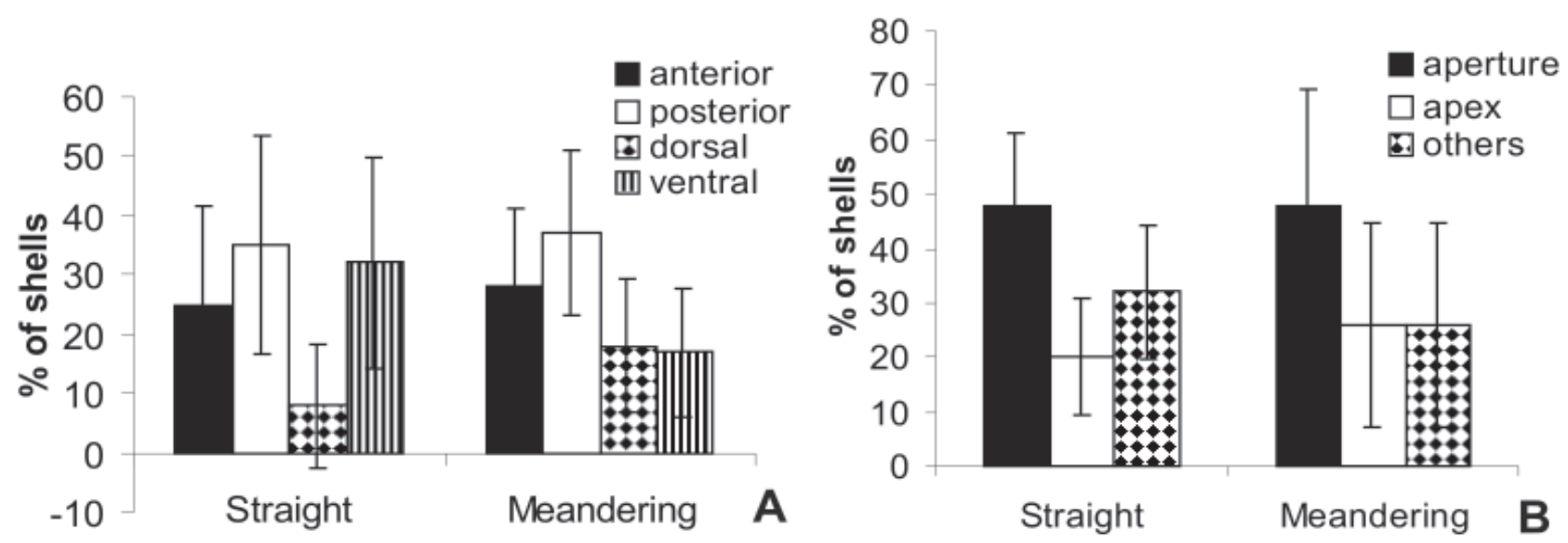

Figure 7. Frequency of the site of the shell fragmentation. A, bivalves; B, gastropods. Error bars show $95 \%$ confidence intervals.

from the meandering sector, the erosion of umbones and the presence of small pits are not significantly different (Figure 13A). Otherwise, in the bivalve shells from the straight sector, the presence of small pits is significantly higher $(p<0.05)$ than the occurrence of large pits (Figure 13A). In the gastropod shells from both sectors, the presence of small pits was frequent in more than $60 \%$ of examined specimens (Figure 13B). On the other hand, gastropod shells with corroded apex were significantly more frequent $(\mathrm{p}<0.05)$ especially in the accumulations from the straight sector (Figure 12B).

\section{DISCUSSION}

\section{Spatial fidelity}

Taphonomic data gathered in the scope of this research indicate that shells in the studied thanatocoenoses suffered small scale spatial mixing. In other words, these are parautochthonous (sense Kidwell et al., 1986; Callender et al., 1990, 1992). Hence, the taxonomic composition of the shelly assemblages is not severely biased by taphonomic processes. Species or associations already recorded in typical 

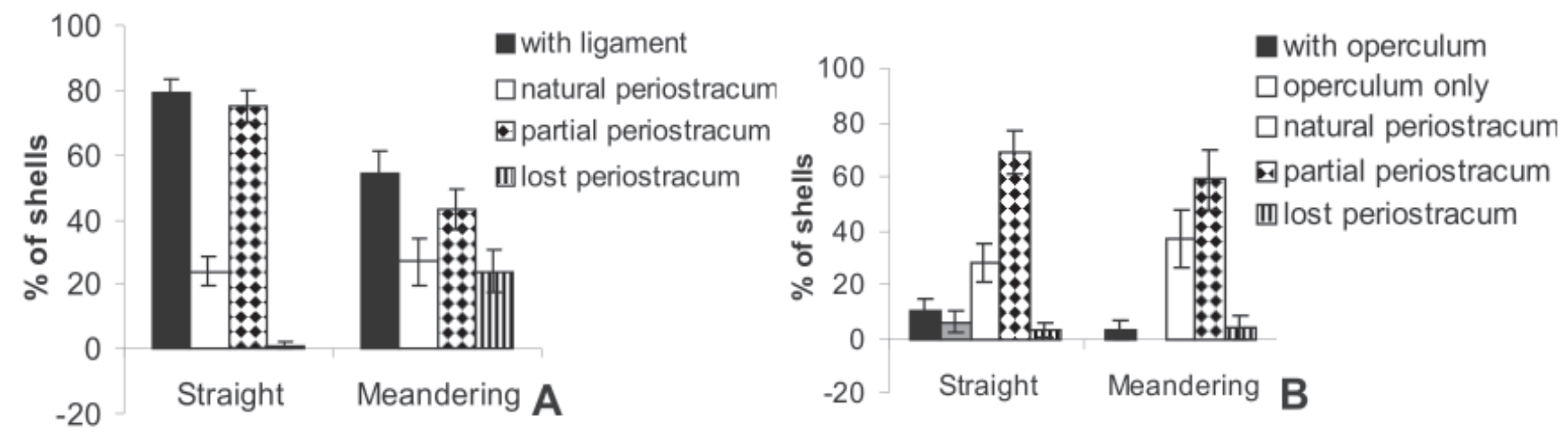

Figure 8. Frequency of the presence of proteinaceous remains. A, bivalves; B, gastropods. Error bars show $95 \%$ confidence intervals.
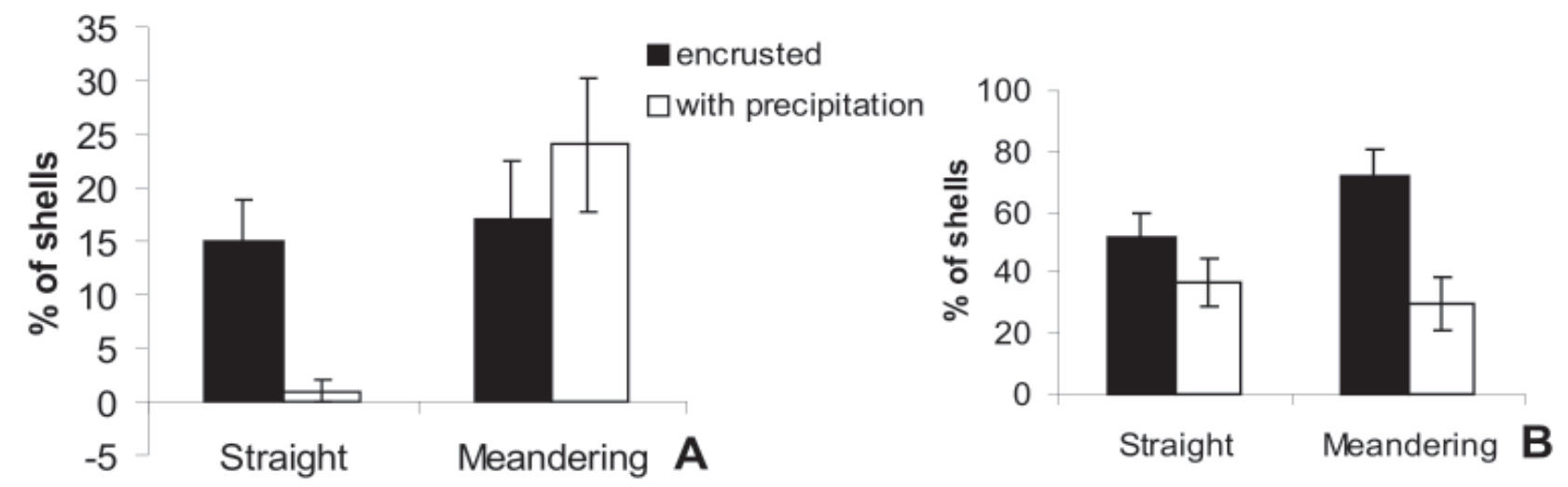

Figure 9. Frequency of shells showing encrustation and precipitation. A, bivalves; B, gastropods. Error bars show $95 \%$ confidence intervals.

lotic environments or ritral areas, in the state of Rio Grande do Sul and adjacent regions, such as Potamolithus ribeirensis, and Chilina parva (Di Persia \& Olazarri, 1986; Pereira et al., 2000a; Simões, 2002), are missing in the study area. In the same way, molluscan species usually recorded in lentic environments, with stagnant waters or low speed water flows, as Lymnaea columella and Stenophysa marmorata, and species belonging to Biomphalaria and Drepanotrema (Pereira et al., 2000b) are also lacking. Hence, the taxonomic composition of the Touro Passo Stream thanatocoenoses, with the absence of genera or species that are typical from true lotic and lentic fluvial environments seems to be consistent with the intermediate hydrodynamic conditions already indicated by the hydrologic data.

The greatest richness and abundance of bivalve species in assemblages of the straight and meandering sectors is indicative of potamic conditions and a stream order greater than third. In other words, low-speed current velocities, inexpressive occurrence of macrophytes and fine-grained bottoms (see Allan, 1996; Naiman \& Bilby, 2001). In fact, such conditions are found in the studied stream and are also corroborated by the presence of filter-feeding mollusks that typically colonize lotic, sandy environments (Figure 3). Yet, the subordinated occurrence of gastropod species is indicative of a less favorable environmental condition to this group thrive. Some gastropods, such as $P$. canaliculata and Biomphalaria are tightly associated with aquatic vegetation (Lanzer \& Schäfer, 1985; Veitenheimer-Mendes et al., 1992;
Pereira et al., 2000b). As commented above, such conditions are not widespread in the studied stream. In addition, these gastropods are commonly found in stagnated waters (Chieffi \& Moretti, 1979; Bonetto et al., 1982), an environmental condition uncommon in the Touro Passo Stream. However, some of the above environmental conditions are observed in the abandoned meander, located at the margins of the straight channel. Hence, the hypothesis that some gastropod shells were transported (parautochthonous) from nearby water bodies cannot be rejected (see Figure 3).

The richness, the abundance and particularly the numerical dominance of the recorded species seems to be a reflex of the distinct environmental conditions that characterize the different sectors of the Touro Passo Stream. These differences are related to the bottom type (grain size), and the hydrologic conditions (e.g., intermittence of the water flow) along the distinct stream channels. High richness of molluscan shells from the assemblages found in the meandering sector seems to be related to the presence of diverse microhabitats, as a response to differences in channel width and depth, water energy, and substrate.

The great abundance of some molluscan species in the assemblages of the straight sector should be related to the high-energy conditions prevailing in this environment. Some species such as $C$. largillierti and $P$. aff. orbigny are very numerous (Table 2). Corbicula largillierti and $P$. aff. orbigny are closely related to $C$. fluminea and $P$. ribeirensis. Both species are able to colonize high-energy settings (Di Persia 

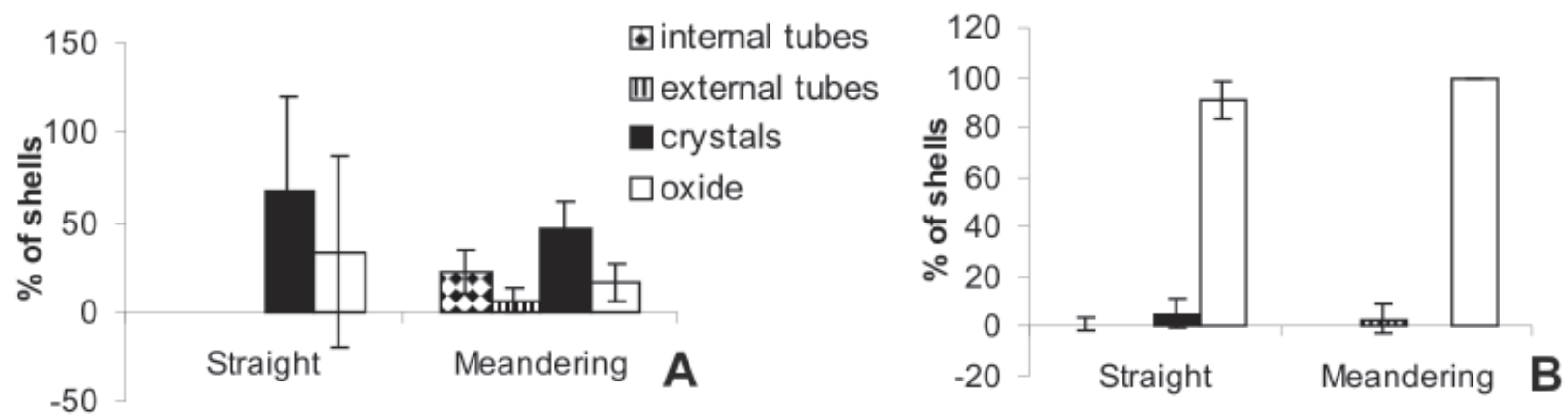

Figure 10. Frequency of the different kinds of precipitation. A, bivalves; B, gastropods. Error bars show $95 \%$ confidence intervals.
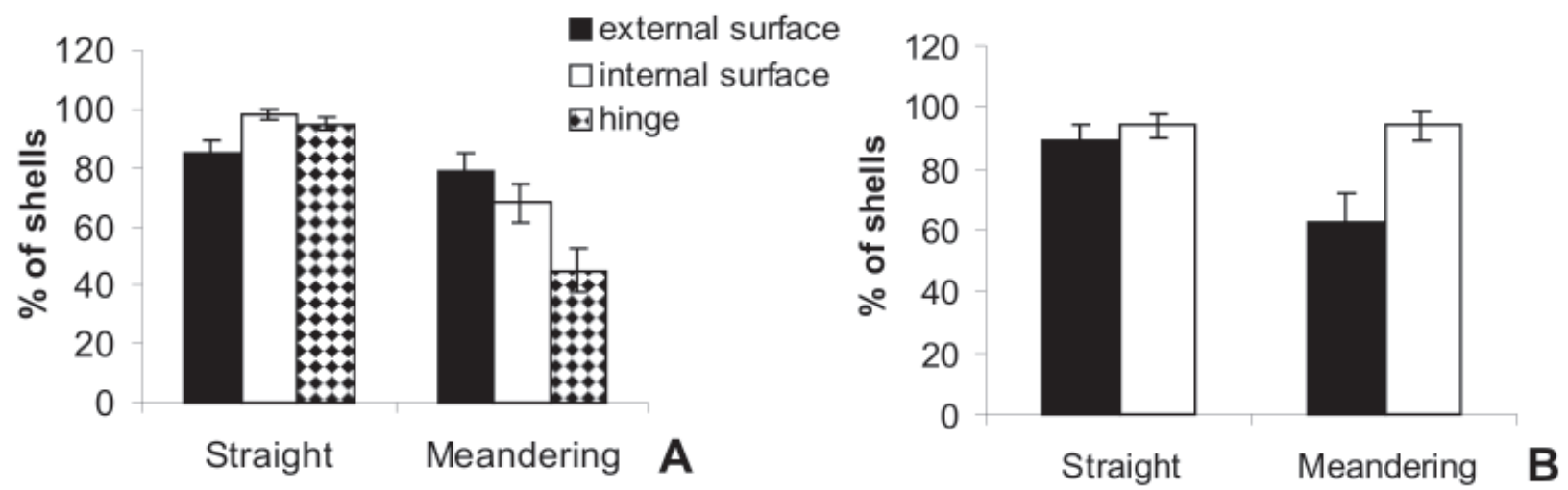

Figure 11. Frequency of low levels of corrasion (eroded extremities, small pits) in the internal and external shell surfaces. A, bivalves; B, gastropods. Error bars show 95\% confidence intervals.

\& Olazarri, 1986; Morton, 1982; Mansur \& Garces, 1988, Simões, 2002). The high frequency of lotic dwellers that are able to cope with high-energy conditions (Figure 3) corroborates the observations above. The dominance of $C$. largillierti in assemblages of the straight sector is indicative of more energetic environmental conditions and more stable flow regime. During the dry season, when drought conditions prevail, $C$. fluminea is not able to move to deeper sites, but can burrow deeper in the sediment (Duarte et al., 1996). It is possible that the allied species $C$. largillierti found in the Touro Passo assemblages have a similar mode of life. Diplodon delodontus wymani, the dominant species in the meandering sector, may move in the bottom, as $D$. charruanus. This species, as M. minuana, is able to actively move to the deepest parts of the stream, during the dry periods (Duarte $e t$ al., 1996). Shells of M. minuana were only recorded in assemblages of the meandering sector. Probably, this is due to its capability to deal with the distinct environmental conditions along the seasons. The predominance of $D$. delodontus wymani in the assemblages of the meandering sector (Station 2) could reflect the intermittent hidrologic conditions prevailing in this channel. On the other hand, the predominance of $C$. largillierti in assemblages of the straight channel (Station 1) may be associated with the more stable environmental conditions of this stream sector.

Potamolithus aff. orbigny and $P$. canaliculata, secondarily dominant in assemblages of both sectors, are more numerous in the straight sector. The presence of the first species could be associated with the more energetic conditions of the straight sector, and the second species with the occurrence of vegetation and backwater conditions. As previously referred, although strong current conditions prevail in the straight sector, some lentic marginal environments are also present. This is the case of the abandoned meander, where $P$. canaliculata and other characteristic species (Biomphalaria spp. and G. moricandi) of this facies are also found.

In summary, the structure and ecological composition of the examined thanatocoenoses are all indicative of a high, fine-scale spatial fidelity of the shells. However, between stations, the data gathered suggest the occurrence of smallscale lateral transport of some species. This is the case of Biomphalaria spp. and $P$. canaliculata, which shells are more frequent in the vegetated (macrophytes) marginal areas of the stream. Shells of these species are also found in the assemblages of the straight sector. The presence of these species is probably due to the transport during flooding events. Under such environmental conditions the marginal areas and the main stream channel are connected. Hence, the lateral transport of Biomphalaria spp. and P. canaliculata shells could not be dismissed under such conditions.

\section{Temporal mixing}

A detailed study on the temporal mixing of the studied assemblages in the way of those available to marine shelly assemblages (e.g., Carroll et al., 2003) is far from the scope of 

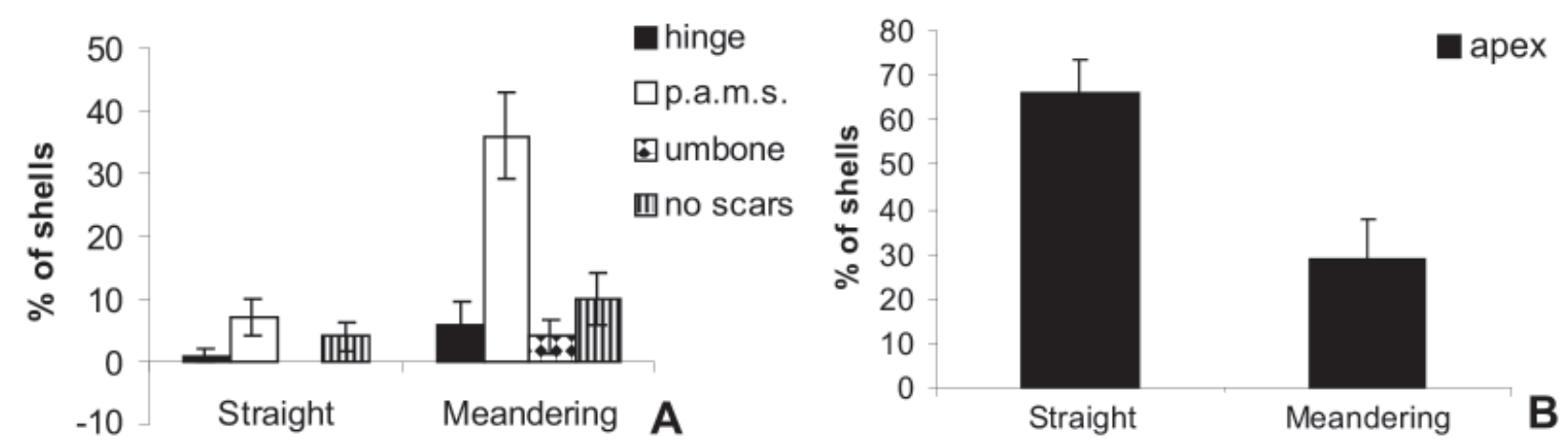

Figure 12. Frequency of high levels of corrasion (loss of apex in gastropods; loss of umbone, hinge, p.a.m. scar, and muscle scars in bivalves). A, bivalves; B, gastropods. Error bars show $95 \%$ confidence intervals.
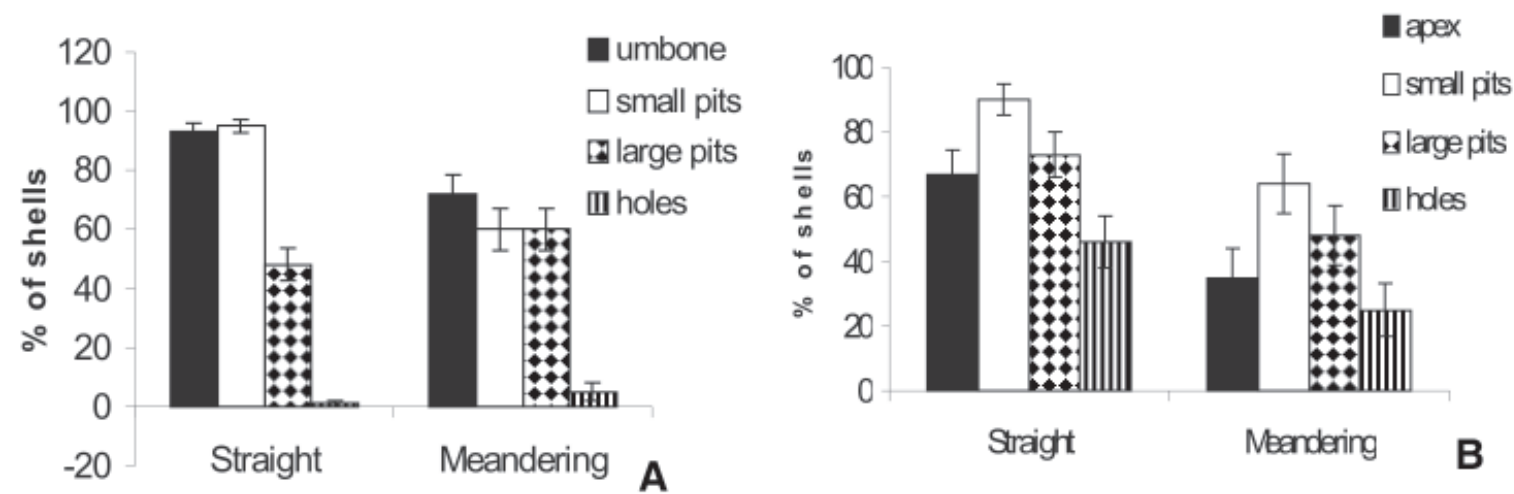

Figure 13. Frequency of the different kinds of external surface alteration. A, bivalves; B, gastropods. Error bars show $95 \%$ confidence intervals.

the present contribution. However, some issues related to the time-averaging of the Touro Passo assemblages are worth to comment. In the meandering sector, there are several riverbanks with Pleistocene fossil-rich layers. These layers enclose gastropod and bivalve shells. Many of these specimens seem to be mixed with the Modern shells found in the riverbed, particularly during the avulsion of channel margins (point bar deposits). When exposed to weathering some fossil gastropods become very fragile, probably due to the small size of these specimens (Oliveira, 1996). The weathered shells simple disintegrate with finger touches. However, large and thick-shelled bivalve fossils have kept shell integrity.

\section{Disarticulation and sorting}

The high rate $(80 \%)$ of disarticulated bivalve shells from the straight sector $(p<0.05)$ seems to be associated to the more energetic conditions prevailing in this channel. However, the similar number $(50 \%)$ of right and left valves of bivalve shells recorded in assemblages of the straight channel (Figure 4A) indicate that disarticulation is not a result of extensive lateral transport and sorting. As for the marine assemblages, intrinsic and extrinsic factors may be responsible for disarticulation.

Corbicula largillierti, a numerically dominant species in the straight sector (Table 2), has shorter and more fragile ligament than D. delodontus wymani and other Unionoida. Shells of this species are usually disarticulated, but a pronounced 50/50 deviation of the right and left valves is not observed. The answer to this question may lie in the environmental conditions of the Touro Passo Stream. This river periodically experiences flooding events, when strong bottom currents prevail. During such events shells of some bivalve species can be dislodged from the substrate and transported alive. As a result, such shells may be deposited outside the sediments where they live under background conditions. This should have occurred with some bivalve shells (C. largillierti) found in the assemblages of the subaerial quadrat (Substation 1). In fact, samplings in this substation were conducted immediately after a flooding episode. After exhumation, specimens of $C$. largillierti have low capability to burrow and reorient themselves into substrate. C. largillierti shells in the top of the sediment may have died right there, after exhumation, undergoing subsequent and rapid disarticulation of the valves, due to the weakness of the ligament, and not as a result of an extensive lateral transport.

\section{Physical/chemical shell disintegration}

As for disarticulation, interplay of extrinsic and intrinsic factors (e.g., hydrodynamic regime, bottom type, predation etc.) may have influenced the rates of fragmentation, corrasion, and shell cracks recorded in the studied bioclasts. Typical signs of mechanical abrasion, such as the loss of ornamentation, umbones, and carina (Parsons \& Brett, 1991) were rarely observed in the studied material (Figure 2F). 
However, typical features produced by shell dissolution, including the chalky texture, the loss of luster and internal valve colors were very common among the examined shells.

Environmental conditions characterized by coarse, hard substrates and periodical strong currents occur in the Touro Passo Stream. However, in this study case, shell fragmentation seems to be, in part, correlated to the acid $\mathrm{pH}$ conditions of the stream water. Under such conditions, dissolution quickly turns shells into fragile bioclasts. It is noteworthy that some bivalve specimens (Unionoida) were found with completely disintegrated shells, which integrity was only kept by the periostracum (Figure 2G).

Cracks were only recorded in thin-shelled mollusks ( $P$. canaliculata and Biomphalaria spp.) and in the very slender shell margins of Anodontites valves. In the marine environment, such conditions are assigned to shells found in sites where acid $\mathrm{pH}$ prevail, and or in the continental slope, where shell fragmentation is virtually low and complete shell disintegration by dissolution (e.g., mussel shells) is prevented by the presence of periostracum (Callender \& Powell, 1992; Callender et al., 1994).

High fragmentation rates are observed for gastropod shells from the straight sector. However, the same is not true to the sympatric bivalve shells. Even for those bivalve shells that are occasionally epifaunal (C. largillierti), fragmentation rate is lower than to gastropod shells. Because the gastropod shells were not extensively transported, and are unsorted, fragmentation seems not to be exclusively mechanical in origin. In other words, the higher fragmentation rates of gastropod shells in the straight sector can be a dissolution artifact. The same seems to be the case of the bivalve fossil shells mixed with the Modern skeletal remains. Mixing and reworking of weathered (dissolved), thin-shelled bivalves during the avulsion of the sediments of point bar deposits in the meandering channel, artificially increases bivalve fragmentation in assemblages found in this stream sector.

In marine environments, mollusk shells with high ratios of surface area to weight (thin-shelled) are more susceptible to dissolution (Flessa \& Brown, 1983; Kidwell \& Bosence, 1991; Callender et al., 1994). Gastropods, such as $P$. canaliculata and Biomphalaria spp., which have very thin and light shells, seem to have been more affected by dissolution in the meandering channel. Conversely, fragmentation is not pronounced to these shells possibly because the quick dissolution. The absence of small fragments of gastropod shells in the meandering sector (Figure 6B) seems to corroborate this assumption.

Isolated holes similar to those produced by the gastropod P. canaliculata (Cazzaniga, 1990) were recorded in several shells of Biomphalaria spp. However, in this case, the holes are covered by the periostracum (Figure 2E), and seem to be produced from the inside and not from the outside of the shells, as drillings made by predators/parasites are. Such holes may be produced by dissolution, too.

There are high frequencies of shells with natural periostracum (50\% to $80 \%$ ) in the studied assemblages (Figure 8). In freshwater environments, one of the main functions of the periostracum is to prevent shell dissolution, especially in those species with a thick covering (Hunter, 1990). Notably, the presence of bivalve shells with no periostracum in assemblages of the meandering sector (@20\%), seems to be related with the presence of reworked fossil specimens. Shells with partially lost periostracum predominate in assemblages of the straight sector $(\mathrm{p}<0.05)$, suggesting that the mechanical remove of this covering is not only caused by dissolution. This condition is also favored by the epifaunal mode of life of the mollusks with this taphonomic condition. The pattern of the shell damages in epifaunal gastropod shells, and in the bivalve shells (Figure 8), seems to corroborate this assumption. The erosion of the periostracum of shells of C. largillierti (a facultative epifaunal species, and dominant gastropod of the straight sector) was previously recorded by Ituarte (1994) in high-energy settings of the La Plata River.

Small levels of corrasion are frequently observed on the shells of the thanatocoenoses of the Touro Passo Stream. Such condition suggests that the corrasion originated quickly after death (see also Parsons \& Brett, 1991). In fact, the presence of calcite precipitations (Figure 2B) and the chalky condition of the inner surface of some recently dead shells (some with tissue remains) indicate that dissolution really occurs soon after death. Epifaunal gastropods with much corroded shells are more frequent in the straight sector, where presumably high rates of abrasion also occur. Hence, corrasion may be due to an interlay of dissolution and abrasion, having multiple origins.

\section{Biological fragmentation of shells}

Shell holes, probably caused by bird pickings were observed in a few specimens $(\mathrm{n}=2)$ of $P$. canaliculata. Studies being conducted by the senior author, on the stomach content of malacophagous fishes from Ibicuí River, of the Rio Grande do Sul State, such as Pterodoras granulosus, Rhynodoras d'orbignyi, Iheringichthys labrosus and Pimelodus maculatus, show that these species do not crush the shells during nourishment. Conversely, valves still articulated, keeping the periostracum and original luster were observed in the stomach contents of these species (similar observations in Olazarri, 1961, 1968; Veitenheimer \& Mansur, 1975). As a matter of fact, among the bivalve shells, only a few specimens $(\mathrm{n}=4)$ showed undoubtedly evidences of crushing, such as symmetric fractures in the posterior region of the matching valves. Usually, for both groups (bivalves and gastropods) (Figure 7) biological induced breakage or shell crushing preferentially occurs in the thinnest regions of the shells.

\section{Chemical precipitations}

It is possible that this taphonomic signature is "analogous", but not "homologous" to those previously recorded in marine shells. The calcium carbonate precipitations in shells of Touro Passo assemblages are irregular tubes (Figure 2; Table 1), and distinct of that figured by Cutler (1995). These precipitations are macroscopic features and seem to be associated to reworked specimens, 
suggesting a possible constructive diagenetic signature (Alexanderson, 1978). In some cases, precipitations show lumen, suggesting an origin related to insect larval cases or root concretions (rhyzoconcretions). Hence, they could be secondary encrustations and/or precipitations. The high frequency of chemical precipitations in the gastropod shells (Figure 9B) suggests that this attribute is highly influenced by the epifaunal mode of life of Biomphalaria spp., $E$. klappenbachi, P. punctiferum, and P. aff. orbigny or by other intrinsic factors. It is important to emphasize here that the thick and dark coverings found in shells of $P$. aff. orbigny (Figure 2D) seem to prevented their dissolution. This is because when the crusts were removed only a few dissolution signs are observed on the shells. For bivalve mollusks, calcium carbonate precipitations were more frequent in shells of the meandering sector. Precipitations made by calcite crystals were only found on the internal surface of the recently dead bivalve shells (Figure 2B). Such structures seem to have been nucleated on remains of mollusk tissues.

Ferruginous deposits have been documented for some freshwater mollusks of the region, as Eupera platensis, $P$. punctiferum, and Biomphalaria glabrata (Doello-Jurado, 1921; Mansur et al., 1991, 2001; Paraense, 2001). Dussart (1979) suggested that Ferrobacteria generated these deposits. However, Swinehart \& Smith (1979) do not recorded these iron bacteria in the shells, suggesting that the iron was directly removed from the sediments. In assemblages of Touro Passo Stream, these iron deposits can be observed in shells of Biomphalaria spp. (Figure 2C), P. canaliculata, and E. klappenbachi. In addition, thick iron crusts were also found in shells of $P$. aff. orbigny (Figure 2D). These iron crusts may have a distinct origin (if compared with the crust found in other sympatric mollusks), since they can be readily detached from the shells. Similar iron crusts were described by Ituarte (1996) in shells of Pisidium vile Pilsbry, 1897, but our poor knowledge on the origin of this kind of crusts and/or precipitations make difficult to determine its taphonomic significance.

\section{CONCLUSIONS}

Thanatocoenoses of the Touro Passo Stream are mainly parautochthonous. Consequently, the great majority of shells in the studied assemblages were preserved within the living habitat. Hence, these assemblages preserved good spatial fidelity and the taphonomic signatures must have been generated in the living environment.

Dissolution seems to be the most important taphonomic process affecting the shells of the studied thanatocoenoses. Abrasion is another important taphonomic process, being probably associated with shell damages. Calcium carbonate precipitations and corrasion are other common taphonomic signatures observed in the studied bioclasts. These seem to be generated soon after the death of shells or even during life. The epipelic life habits of some studied mollusk species may favor the genesis of these signatures during life.
Anyway, dissolution/corrasion in Touro Passo mollusk shells is quali- and quantitatively similar to those recorded in marine assemblages generated in muddy bottoms with acid pore waters.

As previously observed in marine assemblages, the intrinsic factors seem to play an important role in the genesis of some taphonomic signatures. In this study case, this is easily expressed by the occurrence of partially dissolved shells whose integrity was kept only by the presence of periostracum.

Finally, the within-habitat transportation of the freshwater mollusk shells, and their in situ reworking, complemented by the complex origin of some taphonomic signatures, indicate that paleoenvironmental reconstructions based on this kind of data must be complemented by sedimentologic and stratigraphic observations, even for those shells from typical potamic (less energetic) environments.

\section{ACKNOWLEDGMENTS}

We are very indebted to Sergio Martínez, Michal Kowalewski, and Sabrina C. Rodrigues for their thoughtful comments in distinct phases of this manuscript. CBK thanks the Departamento de Zoologia, UNESP/Botucatu, especially the Laboratório de Paleozoologia Evolutiva, for the logistic support. We thank to L. Barbosa for helping in the statistical analysis; to M.L.N. Fransozo for helping in the photographic works; to A.M.F. Salles, J.M. Leme, and S. C. Rodrigues for their constant support and helping in many stages of this research and for the useful comments on the early drafts of this manuscript. This project was financially supported by the Conselho Nacional de Desenvolvimento Científico e Tecnológico (CNPq, grant 151122-02-4). MGS is a researcher of the $\mathrm{CNPq}$.

\section{REFERENCES}

Alexandersson, T. 1972. Micritization of carbonate particles: processes of precipitation and dissolution in modern shallow marine sediments. Bulletin of the Geological Institution of the University of Upsala, 3(7):201-236.

Alexandersson, T. 1978. Destructive diagenesis of carbonate sediments in the eastern Skagerrak, North Sea. Geology, 6:324-327.

Allan, J.D. 1996. Stream ecology: structure and function of running waters. $1^{\mathrm{a}}$ ed. London, Chapman \& Hall, $388 \mathrm{p}$.

Anderson, L.C.; McBride, R.A.; Taylor, M.J. \& Byrnes, M.R. 1998. Late Holocene Record of community replacement preserved in time-averaged molluscan assemblages, Louisiana Chenier Plain. Palaios, 13:488-499.

Best, M.M.R. \& Kidwell, S.M. 2000. Bivalve taphonomy in tropical mixed siliciclastic-carbonate settings. I. Environmental variation in shell condition. Paleobiology, 26(1):80-102.

Bombin, M. 1976. Modelo paleoecológico evolutivo para o Neoquaternário da região da Campanha-Oeste do Rio Grande do Sul (Brasil). A Formação Touro Passo, seu conteúdo fossilífero e a pedogênese pós-deposicional. Comunicações do Museu de Ciências da PUCRS, 15:1-90. 
Bonetto, A.A.; Bechara, J.A. \& Tassara, M.P. 1982. Los moluscos de la familia Planorbidae en el area del rio Parana Medio. Physis, Secc. B, 41(100):1-6.

Brett, C.E. \& Baird, G.C. 1986. Comparative taphonomy: a key to paleoenvironmental interpretation based on fossil preservation. Palaios, 1:207-227.

Briggs, D.J.; Gilbertson, D.D. \& Harris, A.L. 1990. Molluscan taphonomy in a braided river environment and its implications for studies of Quaternary cold-stage river deposits. Journal of Biogeography, 17:623-637.

Brown, M.E.; Kowalewski, M.; Cherry, D.S.; Neves, R.J. \& Schreiber, M.E. 2005. Freshwater mussel shells as environmental chronicles: geochemical and taphonomic signatures of mercury-related extirpations in the North Fork Holston River, Virginia. Environmental Science and Technology, 35:1455-1562.

Callender, W.R. \& Powell, E.N. 1992. Taphonomic signature of petroleum seep assemblages on the Louisiana upper continental slope: recognition of autochthonous shell beds in the fossil record. Palaios, 7:338-408.

Callender, W.R.; Staff, G.M.; Powell, E.N. \& MacDonald, I.R. 1990. Gulf of Mexico hydrocarbon seep communities. V. Biofacies and shell orientation of autochthonous shell beds below storm wave base. Palaios, 5:2-14.

Callender, W.R.; Powell, E.N.; Staff, G.M. \& Davies, D.J. 1992. Distinguishing autochthony, parautochthony and allochthony using taphofacies analysis. Can cold seep assemblages be discriminated from assemblages from the near shore and continental shelf?. Palaios, 7:409-421.

Callender, W.R.; Powell, E.N. \& Staff, G.M. 1994. Taphonomic rates of molluscan shells placed in autochthonous assemblages on the Louisiana Continental Slope. Palaios, 9:60-73.

Carrol, M.; Kowalewski, M.; Simões, M.G. \& Goodfriend, G.A. 2003. Quantitative estimates of time-averaging in brachiopod shell accumulations from a modern tropical shelf. Paleobiology, 29(3):381-402.

Carvalho, O.S.; Nunes, I.M. \& Caldeira, R.L. 1998. First report of Biomphalaria glabrata in the state of Rio Grande do Sul, Brazil. Memórias do Instituto Oswaldo Cruz, 93(1):39-40.

Cazzaniga, N.J. 1990. Predation of Pomacea canaliculata (Ampullariidae) on adult Biomphalaria peregrina (Planorbidae). Annals of Tropical Medicine Parasitology, 84(1):97-100.

Chieffi, P.P. \& Moretti, I.G. 1979. Flutuação mensal na densidade de populações malacológicas em criadouro natural do município de Londrina, Estado do Paraná, Brasil. Revista do Instituto Adolfo Lutz, 39(1):45-50.

Cohen, A.S. 1989. The taphonomy of gastropod shell accumulations in large lakes: an example from Lake Tanganyika, Africa. Paleobiology, 15(1):26-45.

Cummins, R.H. 1994. Taphonomic processes in modern freshwater molluscan death assemblages: implications for the freshwater fossil record. Palaeogeography, Palaeoclimatology, Palaeoecology, 108:55-73.

Cutler, A.H. 1995. Taphonomic implications of shell surface textures in Bahia la Choya, northern Gulf of California. Palaeogeography, Palaeoclimatology, Palaeoecology, 114:219-240.

Darrigran, G. 1995. Distribuición de tres especies del género Heleobia Stimpson, 1865 (Gastropoda, Hydrobiidae) en el litoral argentino del río de la Plata y arroyos afluentes. Iheringia, Série Zoologia., (78):3-8.

Davis, G.M. \& Silva, M.C.P. 1984. Potamolithus: morphology convergence and relationships among Hydrobioid snails. Malacologia, 25(1):73-108.

Di Persia, D.H. \& Olazarri, J. 1986. Zoobenthos of the Uruguay system. In: B.R. Davies \& K.F. Walker (eds.) The Ecology of the River Systems, W. Junk Publishers, p. 623-629.

Doello-Jurado, M. 1921. Una nueva especie de "Eupera" del Rio de la Plata. Physis, 5(19):72-75.

Duarte, M.M \& Dieffenbach, C.O. 1994. Microdistribution and abundance of freshwater Mollusca (Unionacea and Corbiculacea) in Suzana Lake, Southern Brazil. Studies on Neotropical Fauna and Environmental, 29(4):233-250.

Duarte, M.M.; Schirmer, C.L.; Freitas, A.E.C. \& Diefenbach, C.O. 1996. Habitat selection in freshwater mussels (Mollusca:Bivalvia) in Suzana Lake, Southern Brazil. Biociências, 4(2):17-29.

Dussart, G.B.J. 1979. Sphaerium corneum (L.) and Pisidium spp. Pfeiffer - The ecology of freshwater bivalve mollusks in relation to water chemistry. Journal of Molluscan Studies, 45(1):19-34.

Flessa, K.W. \& Brown, T.J. 1983. Selective solution of macroinvertebrate calcareous hard parts: a laboratory study. Lethaia, 16:193-205.

Gilinsky, N.L. \& Bennington, J.B. 1994. Estimating numbers of whole individuals from collections of body parts: a taphonomic limitation of the paleontological record. Paleobiology, 20(2):245-258.

Gray, J. 1988. Evolution of the freshwater ecosystem: the fossil record. Palaeogeography, Palaeoclimatology, Palaeoecology, 62:1-214.

Guerra, A.J.T. \& Cunha, S.B. (orgs.) 1998. Geomorfologia: uma atualização de bases e conceitos. $3^{\mathrm{a}}$ ed. Rio de Janeiro, Bertrand Russel, $472 \mathrm{p}$.

Hannisdal, B. 2004. Clams and brachiopods: chips that pass out of sight. Palaios, 19:507-513.

Henderson, W.G.; Anderson, L.C. \& McGimsey, C.R. 2002. Distinguishing natural and archaeological deposits: stratigraphy, taxonomy and taphonomy of Holocene shell-rich accumulations from the Louisiana Chenier Plain. Palaios, 17:192-205.

Henry, R. \& Simão, C.A. 1985. Spatial distribution of a bivalve population (Diplodon delodontus expansus) (Kuster, 1856) in a small tropical reservoir. Revista Brasileira de Biologia, 45(4):407-415.

Holz, M. \& Simões, M.G. 2004. Taphonomy: an overview of main concepts and applications to sequence stratigraphic analysis. In: E. Koutsoukos (ed.) Applied Stratigraphy, Springer, p. 249278.

Hunter, R.D. 1990. Shell dissolution rate in freshwater pulmonate snails: influence of periostracum and water chemistry. The Nautilus, 104(93):87-91.

Ituarte, C.F. 1994. Corbicula and Neocorbicula (Bivalvia : Corbiculidae) in the Paraná, Uruguay and Rio de la Plata basins. The Nautilus, 107(4):129-135.

Ituarte, C.F. 1996. Argentine species of Pisidium Pfeiffer, 1821, and Musculium Link, 1807 (Bivalvia: Sphaeridae). The Veliger, 39(3):189-203.

Kidwell, S.M. \& Bosence, D.W.J. 1991. Taphonomy and timeaveraging of marine shelly faunas. In: P.A. Allison \& D.E.G. Briggs (eds.) Taphonomy: releasing the data locked in the fossil record, Plenum Press, p. 115-209.

Kidwell, S.M.; Fürsich, F.T. \& Aigner, T. 1986. Conceptual framework for the analysis and classification of fossil concentrations. Palaios, 1:228-238

Kidwell, S.M.; Rothfus, T.A. \& Best, M.M.R. 2001. Sensitivity 
of taphonomic signatures to sample size, sieve size, damage scoring system, and target taxa. Palaios, 16:26-52.

Kowalewski, M. \& Hoffmeister, A.P. 2003. Sieves and fossils: effects of mesh size on paleontological patterns. Palaios, 18:460-469.

Kowalewski, M.; Flessa, K.W. \& Aggen, J.A. 1994. Taphofacies analysis of recent shelly cheniers (beach ridges), northeastern Baja California, Mexico. Facies, 31:209-242.

Kowalewski, M.; Carroll, M.; Casazza, L.; Gupta, N.S.; Hannisdal, B.; Hendy, A.; Krause, R.A.; LaBarbera, M.; Lazo, D.G.; Messina, C.; Puchalski, S.; Rothfus, T.A.; Salgeback, J.; Stempein, J.; Terry, A.C. \& Tomasovych, A. 2003. Quantitative fidelity of brachipodmollusk assemblages from modern subtidal environments of San Juan Islands, USA. Journal of Taphonomy, 1(1):43-65.

Lanzer, R. 1996. Ancylidae (Gastropoda, Basommatophora) na América do Sul: sistemática e distribuição. Revista Brasileira de Zoologia, 13(1):175-210.

Lanzer, R. 1997. Chilina (Basommatophora, Chilinidae) nas lagoas costeiras do Rio Grande do Sul: concha, rádula, habitat e distribuição. Iheringia, Série Zoologia., 82:93-106.

Lanzer, R. \& Schäfer, A. 1985. Padrões de distribuição de moluscos dulceaquícolas na lagoas costeiras do sul do Brasil. Revista Brasileira de Biologia, 45(4):535-545.

Lanzer, R. \& Schäfer, A. 1987. Moluscos dulceaquícolas como indicadores de condições tróficas em lagoas costeira do sul do Brasil. Revista Brasileira de Zoologia, 47(1/2):47-56.

Lanzer, R. \& Schäfer, A. 1988. Fatores determinantes da distribuição de moluscos dulceaquícolas nas lagoas costeiras do Rio Grande do Sul. Acta Limnológica Brasiliensia, 2:649-675.

Leite, P.F. \& Klein, R.M. 1990. Vegetação. In: Geografia do Brasil. Rio de Janeiro, Fundação Instituto Brasileiro de Geografia e Estatística, Diretoria de Geociências, p. 113-150 (Região Sul, v.2).

Lever, J. 1958. Quantitative beach research I. The "left-rightphenomenon": sorting of lamellibranch valves on sandy beaches. Overgenom uit Basteria, 22:64-72.

López-Armengol, M.F. \& Darrigran, G. 1998. Distribuición del gênero neotropical Potamolithus Pilsbry and Rush 1896 (Gastropoda: Hydrobiidae) en el estuário del Río de la Plata. Iberus, 16(2):67-74.

Machado, F.P. 1950. Contribuição ao estudo do clima do Rio Grande do Sul. $1^{\mathrm{a}}$ ed. Rio de Janeiro, IBGE, 91 p.

Mansur, M.C.D. \& Garces, L.M.M.P. 1988. Ocorrência e densidade de Corbicula fluminea (Mueller, 1774) e Neocorbicula limosa (Maton, 1811) na Estação Ecológica do Taim e áreas adjacentes, Rio Grande do Sul, Brasil (Mollusca : Corbiculidae). Iheringia. Sér. Zool., 68:99-115.

Mansur, M.C.D. \& Olazarri, J. 1995. Redescrição, distribuição e preferências ambientais de Anodontites ferrarisi (Orbigny, 1835) revalidada (Bivalvia, Unionoida, Mycetopodidae). Iheringia, Sér. Zool., 79:3-12.

Mansur, M.C.D. \& Veitenheimer, I.L. 1975. Nova espécie de Eupera (Bivalvia: Sphaeridae) e primeiros estudos anatômicos dentro do gênero. Iheringia, Serie Zoologia, 47:23-46.

Mansur, M.C.D.; Anflor-de-Oliveira, L.M. \& Almeida-Caon, J.E.M. 2001. Pisidium punctiferum (Bivalvia, Sphaeridae) dados ecológicos e densidade populacional no arroio Bom Jardim, Rio Grande do Sul, Brasil. Biociências, 9(1):81-97.

Mansur, M.C.D.; Schulz, C.; da Silva, M.C.P. \& Campos-Velho, N.M.R. 1991. Moluscos bivalves límnicos da estação ecológica do Taim e áreas adjacentes, Rio Grande do Sul, Brasil. Iheringia, Sér. Zoologia, 71:43-58.
Mansur, M.C.D.; Valer, R.M. \& Aires, N.C.M. 1994. Distribuição e preferências ambientais dos moluscos bivalves do açude do parque de proteção ambiental COPESUL, município de Triunfo, Rio Grande do Sul, Brasil. Biociências, 2(1):27-45.

Martínez, S. \& Rojas, A. 2004. Quartenary continental molluses from Northern Uruguay: distribution and paleoecology. Quaternary International, 114(1):123-128.

Moreno, J.A. 1961. Clima do Rio Grande do Sul. $1^{\text {a }}$ ed. Porto Alegre, Secretaria da Agricultura do Estado do Rio Grande do Sul, $88 \mathrm{p}$.

Morton, B. 1982. Some aspects of population structure and survival strategy of Corbicula fluminialis (Bivalvia:Corbulacea) from the Pearl River, Peoples Republic of China. Journal of Molluscan Studies, 49(1):1-23.

Naiman, R.J. \& Bilby, R.E. 2001. River ecology: lessons from the Pacific coastal ecoregion. $1^{\text {a }}$ ed. New York, Springer Verlag, $705 \mathrm{p}$.

Olazarri, J. 1961. Sobre moluscos en el contenido estomacal de la enguila común, "Symbranchus marmoratus B1.". Comunicaciones de la Sociedad Malacologica del Uruguay, 1(1):9-10.

Olazarri, J. 1968. Neocorbicula en el contenido estomacal del "armado comum” Pterodoras granulosus (Valenciennes, 1833). Comunicaciones de la Sociedad Malacologica del Uruguay, 2(14):243.

Oliveira, E.V. 1989. Moluscos bivalves do arroio Touro Passo (Rio Grande do Sul), considerações sobre a granulometria do substrato e distribuição das espécies. Curso de Ciências Biológicas, Pontifícia Universidade Católica do Rio Grande do Sul/Campus de Uruguaiana, Monografia de Bacharelado, $22 \mathrm{p}$.

Oliveira, E.V. \& Milder, S.E.S. 1990. Considerações preliminares sobre uma nova fauna de moluscos fósseis da Formação Touro Passo (Pleistoceno Superior - Holoceno). Veritas, 35(137):121-129.

Oliveira, M.L.V. 1996. Moluscos gastrópodes (Hydrobiidae e Ancylidae) da Formação Touro Passo (Pleistoceno Superior), Rio Grande do Sul, Brasil. Curso de Ciências Biológicas, Pontifícia Universidade Católica do Rio Grande do Sul/Campus de Uruguaiana, Monografia de Bacharelado, $30 \mathrm{p}$.

Paraense, W.L. 2001. The schistossome vectors in the Américas. Memórias do Instituto Oswaldo Cruz, 96 (Suppl.):7-16.

Parsons, K.M. \& Brett, C.E. 1991. Taphonomic processes and biases in modern marine environment. In: S.K. Donovan (ed.) The processes of fossilization, Columbia University, p. 23-65.

Parodiz, J.J. \& Hennings, L. 1965. The Neocorbicula (Mollusca, Pelecypoda) of the Parana-Uruguay basin, South America. Annals of Carnegie Museum, 38:69-96.

Pereira, D.; Konrad, H.G. \& Paloski, N.I. 2000a. Gastrópodos límnicos da bacia do rio Camaquã, Brasil. Acta Biologica Leopoldensia, 22(1):55-66.

Pereira, D.; Veitenheimer-Mendes, I.L.; Mansur, M.C.D. \& da Silva, M.C.P. 2000b. Malacofauna límnica do sistema de irragação da microbacia do arroio Capivara, Triunfo, RS, Brasil. Biociências, 8(1):137-157.

Pereira, D.; Inda, L.A.; Consoni, J.M. \& Konrad, H.G. 2001. Composição e abundância de espécies de moluscos do bentos marginal da microbacia do arroio Capivara, Truinfo, RS, Brasil. Biociências, 9(1):3-20.

Pip, E. 1988. Differencial attrition of molluscan shells in freshwater sediments. Canadian Journal of Earth Sciences, 25:68-73.

Silva, M.C.P. 2003. Hydrobiidae (Gastropoda, Neotaenioglossa, 
Rissooidea) da Planície Costeira do Rio Grande do Sul, Brasil. Programa de Pós-graduação em Biologia Animal, Universidade Federal do Rio Grande do Sul, Tese de Doutorado, 344 p.

Simões, R.I. 2002. Comunidade de moluscos bentônicos na área de abrangência da Usina Hidrelétrica Dona Francisca, Rio Jacuí, Rio Grande do Sul, Brasil, fases de pré e pós-enchimento. Programa de Pós-graduação em Biologia Animal, Universidade Federal do Rio Grande do Sul, Dissertação de Mestrado, $123 \mathrm{p}$.

Stanley, M.S. 1970. Relation of shell form to life habits in the Bivalvia (Mollusca). Boulder, Geological Society of America, 296 p. (Memoir 125).

Strahler, A.H. 2004. Physical Geography: science and systems of the Human environment. $3^{\mathrm{a}}$ ed. New York, John Wiley \& Sons, $816 \mathrm{p}$.
Swinehart, J.H. \& Smith, K.W. 1979. Iron and manganese deposition in the periostraca of several bivalve molluscs. The Biological Bulletin, 156:369-381.

Tevesz, M.J.S. \& McCall, P.L. 1979. Evolution of substratum preferences in bivalves (Mollusca). Journal of Paleontology, 53(1):112-120.

Veitenheimer-Mendes, I.L.; Pitoni, V.L.L.; Silva, M.C.P. \& Schröder, N.T. 1986. Levantamento da malacofauna límnica na área de influência daTermoelétrica Jacuí-RS, em julho de 1986. (Relatório Técnico, 52 p., 23 figs.).

Veitenheimer-Mendes, I.L.; Lopes-Pitoni, V.L.; da Silva, M.C.P.; Almeida-Caon, J.E. \& Schröder-Pfeifer, N.T. 1992. Moluscos (Gastropoda e Bivalvia) ocorrentes nas nascentes do rio Gravataí, Rio Grande do Sul, Brasil. Iheringia, Série Zoologia, 73:69-76.

Received in February, 2005; accepted in March, 2006. 